1983

\title{
A Reassessment of the Younger Doctrine in Light of the Legislative History of Reconstruction
}

Donald H. Zeigler

New York Law School, donald.ziegler@nyls.edu

Follow this and additional works at: http://digitalcommons.nyls.edu/fac_articles_chapters

Part of the Civil Procedure Commons, Criminal Law Commons, Fourteenth Amendment Commons, and the Legislation Commons

\section{Recommended Citation}

1983 Duke L.J. 987 (1983)

This Article is brought to you for free and open access by the Faculty Scholarship at DigitalCommons@NYLS. It has been accepted for inclusion in Articles \& Chapters by an authorized administrator of DigitalCommons@NYLS. 


\section{HEINONLINE}

Citation: 1983 Duke L.J. 9871983

Provided by:

New York Law School<br>The Mendik Library

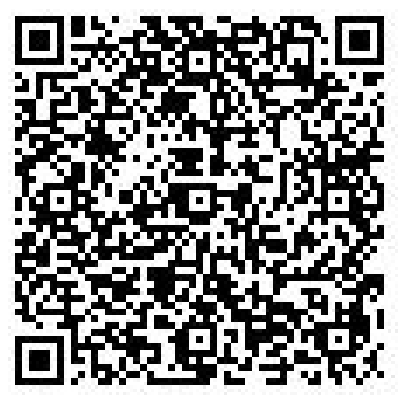

Content downloaded/printed from $\underline{\text { HeinOnline }}$

Sun Aug 13 09:13:06 2017

-- Your use of this HeinOnline PDF indicates your acceptance of HeinOnline's Terms and Conditions of the license agreement available at http://heinonline.org/HOL/License

-- The search text of this PDF is generated from uncorrected OCR text.

-- To obtain permission to use this article beyond the scope of your HeinOnline license, please use:

\section{Copyright Information}




\title{
A REASSESSMENT OF THE YOUNGER DOCTRINE IN LIGHT OF THE LEGISLATIVE HISTORY OF RECONSTRUCTION
}

\author{
DONALD H. ZEIGLER*
}

Recently the Supreme Court extended the doctrine of Younger v. Harris to preclude federal court reform of state criminal and civil justice systems. In this article, Professor Zeigler argues that Younger and its progeny directiy contravene the intent of the Reconstruction Congresses that adopted the fourteenth amendment and enacted numerous pieces of enforcement iegisiation. His research demonstrates that these Congresses intended the federai courts to be the primary enforcer of Reconstruction reform measures. Professor Ziegier conciudes that the federal courts are neglecting their duty to enforce constitutionai safeguards in state justice systems.

\section{INTRODUCTION}

The federal courts have generally refused to entertain suits seeking reform of state criminal and civil justice systems brought pursuant to the fourteenth amendment and 42 U.S.C. $\$ 1983$. This "uncharacteristic remedial timidity" 1 is attributable in part to the Burger Court's farreaching extension of the traditional doctrime that forbids a federal court from enjoining a pending state criminal proceeding in the absence of special circumstances. ${ }^{2}$ The Court signaled the reemergence of

* Professor of Law, Pace University. A.B., Amherst College, 1966; J.D., Columbia University, 1969.

The author wishes to thank Paul Dimond, Donald L. Doernberg, and Judge James D. Hopkins for their helpful comments on drafts of this article. Reference Librarian Ruth Ann Rosner provided valuable assistance in procuring hard-to-find historical materials. The author also gratefully acknowledges the research assistance of Kendra Golden, Sari Jaffe, and Scott Westervelt.

1. Cover \& Aleinikoff, Dialectical Federalism: Habeas Corpus and the Court, 86 YALE L.J. 1035,1036 (1977). The federal courts have been active in reforming other state imstitutions, such as schools and prisons. See infra notes $211-13$ and accompanying text.

2. This doctrine reflects a "judicially developed policy of self-restraint" and combines "principles of comity, equity, and federalism." Zeigler, An Accomodation of the Younger Doctrine and the Duty of the Federal Courts to Enforce Constitutional Safeguards in the State Criminal Process, 125 U. PA. L. Rev. 266, 269-70 (1976).

The Supreine Court first addressed the propriety of federal court intervention in state criminal proceedings in In re Sawyer, 124 U.S. 200, 209-10, 219-20 (1888), and declined to intervene. The Court has taken a fiexible approach to this form of abstention over the years. "During periods of judicial activism, the doctrine has been read narrowly and sometimes ignored, only to be reas- 
this nonintervention doctrine in 1971 in Younger $v$. Harris. ${ }^{3}$ It soon extended Younger, first to bar an injunction against state-initiated civil proceedings "in aid of and closely related to criminal statutes," 4 and then to bar interference with any state-initiated civil proceedings. ${ }^{5} \mathrm{Si}-$ multaneously, the Court expanded Younger to preclude cases requesting systemic reform of state practices and procedures, even though the plaintiffs did not seek to enjoin any pending state court proceedings. ${ }^{6}$ The lower federal courts followed the Supreine Court's lead, ${ }^{7}$ and by the late 1970's the vast area of state administration of justice was effectively free of direct federal court scrutiny under the fourteenth ainendment and section $1983 .^{8}$

The thesis of this article is that the federal courts' refusal to use their equitable powers to reform state justice systens directly contravenes the intent of the Reconstruction Congresses that adopted the fourteenth ainendinent and enacted section 1983. The federal courts

serted during periods of judicial restraint." Zeigler, supra, at 270. For a review of the historical development of the Younger doctrine, see id. at 269-83; Wechsler, Federal Courts, State Criminal Law and the First Amendment, 49 N.Y.U. L. Rev. 740 (1974); Whitten, Federal Declaratory and Injunctive Interference with State Court Proceedings: The Supreme Court and the Limits of Sudicial Discretion, 53 N.C.L. Rev. 591 (1975).

There has been soine disagreement annong scholars whether to call the Younger doctrine a type of abstention. For purposes of this article the term "Younger abstention" will be used, which is consistent with recent Supreme Court usage. See, e.g., Colorado River Water Conservation Dist. v. United States, 424 U.S. 800, 816 (1976). Federal court reluctance to reform state justice systems also is attributable to a separate abstention doctrine first articulated in Railroad Comin'n v. Pullman Co., 312 U.S. 496, 498-501 (1941). This article, however, will not address either Pullman abstention or the abstention doctrines articulated in Burford v. Sun Oil Co., 319 U.S. 315, 317-18, 327-34 (1943), Allegheny v. Frank Mashuda Co., 360 U.S. 185, 188-89 (1959), Louisiana Power \& Light Co. v. City of Thibodaux, 360 U.S. 25, 27-28 (1959), and Colorado River Water Conservation Dist. v. United States, 424 U.S. 800, 817-20 (1976).

3. 401 U.S. 37 (1971). In Younger, the Court refused to entcrtain a first amendment challenge to Cahifornia's Criminal Syndicahism Act, and thus revcrsed a lower court decision that had enjomed Harris's prosecution under that Act. Id. at 40-41. Samuels v. Mackell, 401 U.S. 66 (1971), decided the same day as Younger, refused to pernit federal declaratory relief, which "has virtually the same practical impact as a formal injunction." $I d$. at 72 .

4. Huffman v. Pursue, Ltd., 420 U.S. 592, 604 (1975).

5. Cf. Moore v. Sims, 442 U.S. $415,423 \&$ n.8, 424 (1979) (pohicy of noninterference in proceedings involving important state interests); Trainor v. Hernandez, 431 U.S. 434, 443-44 (1977) (policy of nonimterference in state enforcement proceedings).

6. See Rizzo v. Goode, 423 U.S. 362, 377-80 (1976); O'Shea v. Littleton, 414 U.S. 488, 500 (1974); infra notes 236-60, 278-97 and accoinpanying text.

7. See infra notes $330-46$ and accompanying text.

8. See Cover \& Aleinikoff, supra note 1, at 1038-41; Zeigler, supra note 2, at 266-67. Federal court review of state court decisions involving alleged denials of federal rights by state justice officials remains available through two main cliannels. Final judgments involving federal rights rendered by the highest state court "in which a decision could be had" may be reviewed by the Supreme Court under 28 U.S.C. $\$ 1257$ (1976). And, after exhausting state remedies, individual state criminal defendants unay raise federal constitutional challenges to their convictions by way of federal labeas corpus under 28 U.S.C. § 2254 (1976). 
frequently refer to the legislative history of these Reconstruction measures for guidance in determining the provisions' proper scope and application.9 Younger and its progeny, however, rarely mention the legislative history, ${ }^{10}$ perhaps because equitable restraint finds no support there. Most of the voluminous scholarly commentary on the Younger doctrine does not address the legislative intent of either the fourteenth amendment or section 1983."1 This article fills that void.

Section II addresses the legislative history of Reconstruction. It begins with a brief discussion of the relevance of legislative intent in constitutional and statutory interpretation. It then proceeds to a detailed review of the legislative history of Reconstruction from 1865 to 1871. This review presents a new perspective on congressional concerns and purposes during that era. The record shows that Congress's primary concern was the continuing violence and nnaladministration of justice in the South. Congress's inain purpose in passing the fourteenth amendinent and im enacting wave after wave of enforceinent legislation was to accomplish a systemic reform of southern crimmal and civil justice systems. ${ }^{12}$ The record further shows that the federal courts were to

9. See infra notes $14-19$ and accompanying text.

10. In many Younger cases the majority opinion makes no mention of the Iegislative history of the Reconstruction enactments, despite plaimtiff' reliance on the fourteenth amendment and section 1983. See, e.g., the "Younger sextet": Younger v. Harris, 401 U.S. 37 (1971); Samuels v. Mackell, 401 U.S. 66 (1971); Boyle v. Landry, 40I U.S. 77 (1971); Perez v. Ledesma, 401 U.S. 82 (1971); Dyson v. Stein, 401 U.S. 200 (I971); Byrne v. Karalexis, 401 U.S. 216 (1971); see also Moore v. Sims, 442 U.S. 415 (1979); Tramor v. Hernandez, 431 U.S. 434 (1977); Wooley v. Maynard, 430 U.S. 705 (1977); Juidice v. Vail, 430 U.S. 327 (1977); Rizzo v. Goode, 423 U.S. 362 (1976); Hicks v. Miranda, 422 U.S. 332 (1975); Huffman v. Pursue, Ltd., 420 U.S. 592 (1975); O'Shea v. Littleton, 414 U.S. 488 (1974); Lake Carriers' Ass'n v. MacMullan, 406 U.S. 498 (1972).

The majority does refer to the legislative history in a general way to support its decision not to abstain in Steffel v. Thompson, 415 U.S. 452, 463-65 (1974). References to the legislative history are found more frequently in dissenting or concurring opinions. See, e.g., Trainor v. Hernandez, 431 U.S. at 450, 456 (Brennan, J., dissenting); Juidice v. Vail, 430 U.S. at 339 n.2 (Stevens, J., concurring); Hicks v. Miranda, 422 U.S. at 355-56 (Stewart, J., dissenting); Huffman v. Pursue, Ltd., 420 U.S. at 616-17 (Brennan, J., dissenting); Perez v. Ledesma, 401 U.S. at 106-07 (Brennan, J., concurring in part and dissenting in part); Younger v. Harris, 401 U.S. at 61-63 (Douglas, J., dissenting).

11. Douglas Laycock briefly discusses the legislative history of section 1983 as it relates to abstention in Federal Interference with State Prosecutions: The Need for Prospective Relief, 1977 Sup. CT. REv. 193, 232-34. He concludes that the legislative history does not support abstention. Id.

12. Recent studies of the legislative history of the Reconstruction enactments have centered on the historical justification for desegregation, extension of voting rights, and incorporation of the Bill of Rights in the due process clause of the fourteenth amendment. See R. BERGER, GovERNMENT BY JUDICIARY 5 (1977); see also Bickel, The Original Understanding and the Segregation Decision, 69 HARv. L. Rev. 1 (1955); Curtis, The Fourteenth Amendment and the Bill of Rights, 14 CONN. L. REv. 237 (1982); Kelly, The Fourteenth Amendment Reconsidered: The Segregation Question, 54 Mich. L. Rev. 1049 (1956); Van Alstyne, The Fourteenth Amendment, The "Right" to Vote, and the Understanding of the Thirty-Ninth Congress, 1965 SuP. CT. REv. 33. Although the Iegisla- 
be the primary enforcers of this program through substantial intervention in the day-to-day workings of southern justice systems. Congress firmly and repeatedly rejected the notion that the federal courts should stay their hand in favor of theoretically available, but demonstrably ineffective, state court remedies.

Section III examines the Younger doctrine in light of the legislative history of Reconstruction, and concludes that Younger and its progeny are wholly inconsistent with the congressional purposes. The legislative history contains specific and repeated commands to the federal courts to intervene when state criminal and civil justice systems fail to protect fundainental rights. Thus, by declining to exercise jurisdiction, the federal courts neglect their duty to ensure that state justice systems function in a manner consistent with the requirements of the federal constitution. Section III also explains briefly the inconsistency between the Younger doctrine and the Supreme Court cases refusing to require exhaustion of state remedies im section 1983 cases.

\section{A New Perspective on the Legislative History of RECONSTRUCTION}

\section{A. The Relevance of Legislative Intent.}

The Supreine Court has explicitly recognized the importance of legislative intent ${ }^{13}$ in construing the fourteenth amendment and the Reconstruction legislation conferring jurisdiction and prescribing remedies. ${ }^{14}$ In recent years, the Court has canvassed and recanvassed the legislative debates on section 1 of the Civil Rights Act of $1871^{15}$ to determine whether government officials are immune from suit im section

tive debates addressed all these topics, the predominant topic throughout Reconstruction was the maladministration of southern justice.

13. The debate between those who would interpret constitutional provisions and remedial statutes to reflect evolving norms and values and those who would limit application of such mcasures to matters contemplated by their framers has been rekindled in recent years. See, e.g., $\mathrm{R}$. Berger, supra note 12; J. Choper, Judicial Review and the National Political Process (1980); J. Ely, DEMOCRACY AND DisTRUST (1980). Although the author is inclined to the former, noninterpretivist, position, this article will meet the more exacting requirements of the latter, interpretivist, viewpoint.

14. For example, the Supreme Court has examined the legislative history of the fourteenth amendment to determime whether Congress intended to make the guarantees of the Bill of Rights applicable to the states. See Adamson v. California, 332 U.S. 46, 70, 72 (1947) (Black, J., dissenting). A review of that history also played a role $\mathrm{m}$ the Court's decision in Brown v. Board of Educ., 347 U.S. 483, 489 (1954). See R. BERGER, supra note 12, at 117-33; Bickel, stipra note 12, at 1-2; see also Kush v. Rutledge, 103 S. Ct. 1483, 1483-88 (1983) (examining the Reconstruction period legislative debates to determine the reach of jurisdictional and remedial statutes of that era).

15. Section $I$ is currently codified at 28 U.S.C. $\S 1343$ (3) (Supp. V 198I) and 42 U.S.C. $\S 1983$ (Supp. V 1981). For the text of these sections, see infra note 165 . 
1983 actions, ${ }^{16}$ whether states and municipalities are persons within the meaning of the statute, ${ }^{17}$ and whether section 1983 is an exception to the Anti-Injunction Act. ${ }^{18}$ In its 1982 term, the Court also determined legislative history decisive when it declined to require exhaustion of state administrative remedies in section 1983 actions:

$[\mathrm{L}]$ egislative purpose . . . is of paramount importance in the exhaustion context because Congress is vested with the power to prescribe the basic procedural scheme under which claims may be heard in federal courts . . . . [T]he initial question whether exhaustion is required should be answered by reference to congressional intent; and a court should not defer the exercise of jurisdiction under a federal statute unless it is consistent with that intent. ${ }^{19}$

If the legislative history of the Reconstruction era is crucial to determination of these issues, it seems equally relevant in determining whether the federal courts may properly decline to exercise jurisdiction in cases brought pursuant to the fourteenth amendment and section 1983.

16. See, e.g., Briscoe v. Lahue, 103 S. Ct. 1108, 1116-18 (1983); Scheuer v. Rhodes, 416 U.S. 232, 242-44 (1974).

17. See Quern v. Jordan, 440 U.S. 332, 340-43 (1979) (holding that states are not persons). Compare Monell v. New York City Dep't of Social Servs., 436 U.S. 658, 664-90 (1978) (holding that inunicipahities are persons) with Monroe v. Pape, 365 U.S. 167, 187-91 (1961) (holding that they are not). The Court also considered the legislative history of section 1983 in determining that municipalities were not entitled to a good-faith defense, see Owen v. City of Independence, 445 U.S. 622, 635-38 (1980), and that punitive dainages could not be assessed against thein, see City of Newport v. Fact Concerts, Inc., 453 U.S. 247, 258 (1981) ("It is by now well settled that the tort hability created by $\S 1983$ cannot be understood in a historical vacuun.").

18. Mitchum v. Foster, 407 U.S. 225, 240-42 (1972). The Court also reviewed the legislative history of section 1983 in determining that the statute "encompasses claims based on purely statutory violations of federal law," Maine v. Thiboutot, 448 U.S. 1, 3 (1980), and that neghigence is actionable under section 1983, see Parratt v. Taylor, 451 U.S. 527, 534-35, 544 (1981). But see Pennhurst State School v. Halderman, 451 U.S. 1 (1981) (Court questioned whether alleged failure of state officials to provide adequate "assurances" to the Secretary of Health and Hunan Services that the "human rights" of retarded persons were protected, as required by federal statute, constituted a denial of a right secured by the law of the United States within the ineaning of section 1983).

19. Patsy v. Board of Regents, 457 U.S. 496, 501-02 (1982). Abstention is conceptually sinilar to exhaustion, because abstention forces the federal plaintiff to exhaust state judicial renuedies before turning to federal courts for rehef. Patsy thus provides particularly strong support for exaunining the abstention doctrime in light of the legislative history of the Reconstruction era. See infra note 349.

Recent cases restricting federal court discretion to imply private rights of action to reunedy violations of federal statutes are consistent with the Court's approach in Patsy because they reaffirm the importance of congressional intent. In deciding whether to imply a cause of action under a statute that does not exphcitly create one, the Court appears to have moved froin the four-factor test of Cort v. Ash, 422 U.S. 66, 78 (1975), to a single-factor test of legislative intent. See Touche Ross \& Co. v. Redington, 442 U.S. 560,568 (1979) ("our task is linited solely to determining whether Congress intended to create [a] private right of action"). But see California v. Sierra Club, 451 U.S. 287, 293 (1981) (suggesting that although the ultinate issue is legislative intent, the Cort factors remain the criteria for discerning that intent). 


\section{B. The Legislative History of Reconstruction.}

One embarks on a journey through the legislative history of the Reconstruction era with a certain caution, for previous travelers have seen a countryside as different as the Rocky Mountains and the plains of Kansas. ${ }^{20}$ The journey will of necessity be a long one because the legislative debates of many years must be reviewed. ${ }^{21}$ The constitutional amendinents and statutes passed during Reconstruction are interrelated. Therefore, they cannot be treated as self-contained units and interpreted without reference to other measures enacted during the period. Fimally, it is inperative to review with some care the evils Congress sought to redress for guidance in deciding "what current conditions closely resemble the historic wrongs that may have led to the passage of a given provision." 22 Fortunately, the Reconstruction legislators dwelt at length on the evils they sought to cure.

1. Presidential Reconstruction and the Black Codes. The Reconstruction program of President Johnson immediately following the Civil War, along with the South's enactınent of the Black Codes, set the stage for congressional reconstruction. President Johnson viewed reconstruction as an executive function. ${ }^{23}$ With Congress out of session, he moved quickly in the summer and fall of 1865 to restore the southeru states to the Union. ${ }^{24}$ Unfortunately, the President "let the spoils control the victor." 25 President Johnson appoimted provisional governors for the southern states, ${ }^{26}$ but instructed the governors to give state residents a relatively free hand in forming new governments. ${ }^{27}$ Consti-

20. Compare, e.g., R. BERGER, supra note 12 with Dimond, Strict Construction and Judicial Review of Racial Discrimination under the Equal Protection Clause: Meeting Raoul Berger on Interpretivist Grounds, 80 Mich. L. Rev. 462, 463 (1982) and Soifer, Protecting Civil Rights: A Critique of Raoul Berger's History, 54 N.Y.U. L. REv. 651 (1979).

21. As Raoul Berger has reminded investigators, "it is not enough to [state] that the evidence is overwhelming. It is necessary to pile proof on proof, even at the risk of tedium, so that the reader may determine for himself whether it is overwhelming or inconclusive." $R$. BERGER, supra note 12 , at 8 .

22. Dimond, supra note 20, at 472; see also J. ELY, supra note 13, at 13.

23. J. Randall \& D. Donald, The Civil War and Reconstruction 559-60 (2d ed. 1961); see also 2 J. BlaINE, TwentY YeARs of CoNGress 70 (1886).

24. J. RANDAll \& D. Donald, supra note 23, at 558.

25. H. Hyman \& W. Wiecek, Equal Justice UNDER LaW 315 (1982).

26. 2 J. BLAiNe, supra note 23, at 78-80; J. RANDALL \& D. Donald, supra note 23, at 562.

27. See, e.g., E. McPherson, The Political history of the United States of America During the Period of Reconstruction 11-12 (De Capo Press ed. 1972) (reprinting the proclamation estabhishing procedures for the reconstruction of North Carolina). The provisional governors generally retained existing state officials in office. J. RANDALL \& D. DONALD, supra note 23, at 562. Moreover, the "[d]ecrees of the state courts in ordinary civil and criminal matters were confirmed." Id. 
tutional conventions called by the provisional governors were dominated by the white power structure that had controlled the South during the war, ${ }^{28}$ and delegates "exhibited a remarkable indifference to Northern opinion." 29 In due course elections were held for state and local offices and for Congress. ${ }^{30}$ All those elected were white, ${ }^{31}$ and many were foriner confederate offcials. ${ }^{32}$

The freedmen did not fare well under the new regimes. Carl Schurz, who toured the South from July to October, 1865 , at the President's request, reported that former slaveowners sought effectively to reenslave the blacks by widespread intimidation and violence. ${ }^{33}$ In addition, between November, 1865 and March, 1866, the newly-elected legislatures in all of the ex-Confederate states except Texas and Arkansas enacted comprehensive laws ${ }^{34}$ regulating the freedmen. These Black Codes ${ }^{35}$ controlled and disciplined farm laborers by prohibiting "vagrancy" 36 and desertion from work. ${ }^{37}$ Children were to be forcibly apprenticed. ${ }^{38}$ Freedmen were forbidden to engage in certain occupations without obtaining a license, ${ }^{39}$ and freedoin of movement was curtailed. ${ }^{40}$ Freedmen were not allowed to carry weapons. ${ }^{41}$ Other provisions regulated general conduct and etiquette toward whités.42

28. 2 J. BLAINE, supra note 23 , at $80-81$.

29. J. RANDALl \& D. DonalD, supra note 23 , at 571 .

30. H. HyMAN \& W. WIECEK, supra note 25 at 304; J. RANDALL \& D. Donald, supra note 23 , at $562-63$.

31. H. HYMAN \& W. WIECEK, supra note 25 , at 304.

32. J. RANDALl \& D. Donald, supra note 23 , at 571

33. Report of Carl Schurz on the States of South Carolina, Georgia, Alabama, Mississippi, and Louisiana, S. EXEC. Doc. No. 2, 39th Cong., 1st Sess. $17-20$ (1865).

34. C. Fairman, Reconstruction and Reunion, 1864-88, Part ONe, at 106-07 (1971).

35. For a compilation of the Black Codes, see Howard, Laws in Relation to Freedmen, $\mathrm{S}$. EXEC. Doc. No. 6, 39th Cong., 2d Sess. 170-230 (1867). An almost verbatim recitation of the Codes is presented in E. MCPherson, supra note 27, at 29-44. See generally D. NovaK, ThE Wheel of Servitude: Black Forced Labor After Slavery (1978); T. Wilson, The Black Codes of the South (1965); F. Wood, Black SCare: The Racist Response to EmancipaTION AND RECONSTRUCTION (1968).

36. See, e.g., S. ExEc. Doc. No. 6, 39th Cong., 2d Sess. 170-71 (Alabaina), 192-93 (Mississippi), 218-19 (South Carolina), 229-30 (Virginia) (1867).

37. See, e.g., id. at 181-82 (Louisiana), 193-95 (Mississippi).

38. See, e.g., id. at 172-74 (Alabama), 180-81 (Georgia), 186 (Louisiana), 187-88 (Maryland), 190-91 (Mississippi), 200-02 (North Carolina), 209-11 (South Carolina).

39. A South Carolina law enacted December 21, 1865, for example, provided that no black could be an artisan, mechamic, or shopkeeper, or pursue any other busimess except farm laborer or servant, without first obtaining a license from a judge of the district court. A fee was required, and the license could be revoked at any time if coinplaints were made. Id. at 215 .

40. Tlie Mississippi "Civil Rights" Act of November 25, 1865 required that a freedman be able to show written evidence of a lawful home and employment in the form of a "license" from the mayor of a town or board of police. Id. at 194; see also id. at 205 (South Carolina).

41. See, e.g., id. at 174 (Florida), 183 (Louisiana), $195-96$ (Mississippi), 204 (South Carolima).

42. See, e.g., id. at 174 (Florida), 196 (Mississippi). 
The framers of the Black Codes envisioned that the southern criminal justice system would be the primary enforcement mechanism. Indeed, the Codes bristled with harsh criminal sanctions. ${ }^{43}$ In some states, new courts were created to handle the expected flow of cases, ${ }^{44}$ while in others the jurisdiction of existing courts or officials was enlarged. 45

Although the Codes generally were racially discriminatory on their face, soine provisions contained no reference to race, ${ }^{46}$ or purported to apply equally to blacks and whites. ${ }^{47}$ The facially neutral provisions normally were confined to blacks in their application, ${ }^{48}$ but

43. For example, under Florida's vagrancy statute, every able-bodied person who had "no visible means of living" and was unemployed could be arrested by any justice of the peace or judge of the county criminal court. E. MCPHERSON, supra note 27, at 39 . If the defendant could not give "sufficient surety" of future industry, he was subject to trial. Upon conviction, he could be sentenced to labor or to prison for up to one year. If sentenced to labor, the sheriff or court officer was to hire out the defendant. Id. According to the Mississippi Code, laborers who quit the service of their employers before the end of the term without good cause forfeited wages earned up to that time. S. ExEC. Doc. No. 6, 39th Cong., 2d Sess. 193-94 (1867). Upon the affidavit of an employer that a freedman had illegally deserted his job, a justice of the peace or meinber of the board of police was authorized to issue an arrest warrant. Id. at 195 . Upon returning the absent black, a policeman or private party was to be paid five dollars plus inileage. Similarly, the Mississippi child apprenticeship law required all sheriffs, justices of the peace, and other officers to report to probate courts all black children whose parents could not support them so that the court could apprentice the children to a suitable person. Id. at 190. The former owner of the children was given a preference. Id. If an apprentice left without the master's consent, the child could be forcibly brought before a justice of the peace. A continuing refusal to return could result in a jail sentence. Id. at 190-91.

44. In Alabama, a county court was established for the trial of misdemeanors. E. MCPHERsoN, supra note 27, at 34. In South Carolina, district courts were established having exclusivc jurisdiction of all civil cases where one or both parties were black and of all criminal cases where the accused was black. S. ExEc. Doc. No. 6, 39th Cong., 2d Sess. 206 (1867). In Florida, a county criminal court was created by the Act of January 11,1866 to hear various charges, including malicious umischief, vagrancy, and all misdemeanors. E. MCPHERson, supra note 27, at 38 . In an apparent attempt to achieve the sort of assembly-linc efficiency that characterizes today's big-city arraignment sessions, the Act provided that "no presentment, indictment, or written pleadings shall be required." Id.

45. In Alabama, justices of the peace were given jurisdiction over offenses such as vagrancy, larceny, and assauit where no weapon was used. E. MCPHerson, supra note 27, at 34. Mississippi's vagrancy act gave justices of the peace, mayors, and aldermen jurisdiction to try vagrancy questions. S. ExEC. Doc. No. 6, 39th Cong., 2d Sess. 192 (1867).

46. Georgia's vagrancy law, for example, applied to "all persons" able to work and having no visible and known means of support. E. MCPHERSON, supra note 27, at 33. A new Alabama penal code made no distinction on account of race. Id. at 34.

47. Mississippi's vagrancy law applied not only to freedmen, but also to all white persons assembling with freedmen or usually associating with them. S. ExEC. Doc. No. 6, 39th Cong., 2d Sess. 192 (1867).

48. 2 J. BLAINE, supra note 23, at 97-98; see also Amsterdam, Criminal Prosecutions Affecting Federally Guaranteed Civil Rights: Federal Removal and Habeas Corpus Jurisdiction to Abort State Court Trials, 113 U. PA. L. REv. 793, 815-16 (1965); Dimond, supra note 20, at 474-75. 
some were aimed at whites serving in the Union Army or the Freedmen's Bureau ${ }^{49}$ who sought to aid the freedmen..$^{50}$

2. The Thirty-Ninth Congress, First Session. The pent-up frustration caused by President Johnson's ineffectual Reconstruction program and the Black Codes burst forth in Congress when it finally convened on December 4,1865 . By prearranged plan, ${ }^{51}$ newly-elected representatives from the rebel states were not aliowed to take their seats in the House.52 Also by prearrangement, Thaddeus Stevens, the leader of House Republicans, ${ }^{53}$ submitted a resolution calling for creation of a joint committee of fifteen House and Senate nembers to inquire into conditions in the South and to consider appropriate legislation. ${ }^{54}$ The resolution passed overwhelmingly. ${ }^{55}$

In the days that followed, a steady stream of bills, resolutions, and proposed constitutional amendments concerning Reconstruction flowed into the legislative hopper. ${ }^{56}$ The Black Codes and the maladmimistration of southern criminal and civil justice were primary con-

49. The Freedmen's Bureau was creatcd by an Act of March 3, 1865, ch. 90, 13 Stat. 507, to aid blacks in making the transition to freedom. The Bureau sought to find employment for blacks, and often mediated in contractual disputes with the freedmen's former owners. The Bureau also ran a system of special courts in an attempt to secure fair treatment for freedinen. See $2 \mathrm{~J}$. BLAINE, supra note 23, at 162-65; J. RANDALL \& D. DoNALD, supra note 23, at 576-77; tenBroek, Thirteenth Amendment to the Constitution of the United States: Consummation to Abolition and Key to the Fourteenth Amendment, 39 CALIF. L. REv. 171, 184 (1951). Congress's attempt to enlarge the Bureau and extend its jurisdiction is discussed infra at notes 64-79 and accompanymg text. See generally D. Nieman, To Set the Law in Motion: The Freedman's Bureau and The Legal RightS OF BLACKS, 1865-1868 (1979).

50. Many codes, for example, prescribed criminal penalties for inducing a freedman to leave his employer. See, e.g., S. ExEC. Doc. No. 6, 39th Cong., 2d Sess. 171-72 (Alabama), 177 (Florida), 185 (Louisiana), 195 (Mississippi), 227 (Virginia) (1867). In addition, hundreds of white southerners used Code provisions to bring civil suits against Army and Bureau personnel for interferimg with blacks' labor contracts and for other alleged wrongs. H. HYMAN, A MORE PERFECT UNION 452-53 (1973); H. HYMAN \& W. WIECEK, supra note 25, at 322-23.

51. C. FAIRMAN, supra note 34, at 117; B. KENDRICK, JOURNAL OF THE JOINT COMMITTEE OF FIFTEEN ON RECONSTRUCTION 142 (1914).

52. Cong. Globe, 39th Cong., lst Sess. 3-4 (1865). The southern congressional delegations mcluded many men who had held high civilian or inilitary positions under the Confederacy. See W. Hesseltine, Confederate Leaders in the New South 93-147 (1950).

53. J. RANDALl \& D. DoNALD, supra note 23, at 568.

54. Cong. Globe, 39th Cong., lst Sess. 6 (1865).

55. Id. The Joint Committee played a central role in the Thirty-Ninth Congress. The fourteenth amendment was drafted and revised in its ineetings. The Committee's creation and proceedings have been examined in detail by many scholars. See, e.g., C. FAIRMAN, supra note 34, at 118-24, 131-33, 1207-1300; B. KENDRICK, supra note 51, at 137-47.

The opeming session of the Senate also focused on Reconstruction. Senator Sumner introduced mine separate measures on the subject, CONG. GLOBE, 39th Cong., 1st Sess. 2 (1865), and Senator Wilson introduced a bill specifically to outlaw the Black Codes, id. at 39.

56. See, e.g., Cong. Globe, 39th Cong., 1st Sess. 9, 10, 14, 69, 84-87 (1865). 
cerns. ${ }^{57}$ Some legislators sought immediate action on these problems, ${ }^{58}$ but the Senate leadership wanted more time, both to allow the thirteenth amendment with its enforcement provision to become effective ${ }^{59}$ and to develop comprehensive measures in committee..$^{60}$

On January 5, 1866, Senator Lyman Trumbull, the chairman of the Judiciary Committee, introduced two related bills. ${ }^{61}$ The first, the Freedmen's Bureau bill, was designed to enlarge the powers of the Bureau. The second, the Civil Rights bill, sought to "protect every individual in the full enjoyment of the rights of person and property."62 Key provisions of both bills were specifically directed at the Black Codes and the pervasive discrimination against freedmen and white loyalists in southern justice systems. ${ }^{63}$

(a). The Freedmen's Bureau Bill. Section 7 of the Freedmen's Bureau bill declared that whenever in any of the rebel states,

in consequence of any State or local law, ordinance, police or other regulation, custom or prejudice, any of the civil rights or imınumities belonging to white persons, imcluding the right to make and enforce contracts, to sue, be parties and give evidence, . . . and to have full and equal benefit of all laws and proceedings for the security of person and estate . . . are refused or denied to negroes . . . on account of race ... or wherein they . . . are subjected to any other or different punishment ... . for the commission of any act or offence than

57. See, e.g., id. at 10 (remarks of Rep. Stevens), 14 (Rep. Bimgham), 39-42 (Sen. Wilson), 9198 (Sen. Sumner).

58. On December 13, Senator Wilson urged immediate passage of his bill to outlaw the Black Codes. Id. at 39-42. On December 20, Senator Sumner gave a lengthy speech urging quick enactment of Wilson's bill. Because the Black Codes were enforced in the southern court system, Senator Sumner also proposed taking virtually all cases in which blacks were parties out of the local and state courts and vesting exclusive jurisdiction over such cases in the federal courts. Such cases were to be regarded as arising under the Constitution of the United States. Id. at 91. This provision, although not enacted, demonstrated Congress's frustration with the workings of the southern courts and its willingness to have the federal courts intervene to help reinedy the problen.

59. Id. at 41 (remarks of Sen. Sherman), 43 (Sen. Trumbult). The thirteenth amendment became effective on December 18, 1865. See C. FAIRMAN, supra note 34, at 1161.

60. Cong. GloBe, 39th Cong., 1st Sess. 42-43, 77 (1865) (remarks of Sen. Trumbull). Trumbull believed that such legislation was appropriate under the enforcement clause of the thirteenth amendment. Id.

61. Id. at 129 (1866). The day began with Senator Sumner reading a petition recounting the contmuing violence against blacks in Alabama and the abuse of the state's criminal justice system. Id. at 127.

62. Id. at 77 .

63. In the discussion that follows, the Freedmen's Bureau bill, the Civil Rights bill, and the fourteenth amendment are described individually for clarity of presentation. As Harold Hyman and William Wiecek caution, however, debates on these measures "are all but mseparable, and contemporaries did not separate them. Indeed, attempts to do so too sharply imcur the risk of obscuring the essentials which the proponents of these measures sought." H. HYMAN \& W. WIECEK, supra note 25, at 413. 
are prescribed for white persons committing like acts . . . it shall be the duty of the President . . . to extend military protection and jurisdiction over all cases affecting such persons so discriminated against. 64

Section 8 stated that any person who, under color of state law, deprived any person of the rights secured in section 7 would be guilty of a misdemeanor and could be punished by fine of up to $\$ 1000$ or imprisonment for up to one year, or both. ${ }^{65}$ Section 8 broadly defined the jurisdiction of Bureau courts as follows:

[I]t shall be the duty of the officers and agents of this bureau to take jurisdiction of, and hear and determine all offenses committed against the provisions of this section, and also of all cases affecting negroes . . . or other persons who are discriminated against in any of the particulars inentioned in the preceding section of this act. 66

These provisions contemplated extensive federal intervention in the administration of justice in the South, ${ }^{67}$ and the debates on the bill confirm that such intervention is precisely what Congress intended. Proponents in both houses focused upon the evils the bill was designed to address-the Black Codes and the maladministration of justice by southern executive and legislative officials. ${ }^{68}$ The federal legislators made it clear that the bill was not limited to blacks, but extended protcction to whites as well. ${ }^{6}$ Opponents strongly criticized the broad sweep of sections 7 and $8,{ }^{70}$ and complained that the powers granted the Freedmen's Bureau would cause widespread conflict between the Bureau and state court personnel. ${ }^{71}$ Senator Trumbull stressed that the Bureau courts were temporary, and would relinquish jurisdiction when

64. E. MCPHERSON, supra note 27, at 73-74.

65. Id. at 74.

66. Id. The Freedmen's Bureau bill aiso conferred broad grants of authority on the President and Freedmen's Bureau officials to provide assistance to freedmen. Land was to be set aside for them, and asylums and schools built. Id. at 73. The Secretary of War was authorized to direct emergency allocations of food, clothing, and medical supplies, and to provide shelter. Id.

67. The language of sections 7 and 8 is not limited to statutory denial of rights. Section 7 proscribes discrimination not only "in consequence of any state or local law" but also by "custom or prejudice." Section 8 allows Bureau courts to take jurisdiction of any case where a person suffers discrimination proscribed by section 7 .

68. See Cong. Globe, 39th Cong., 1st Sess. 340-43 (remarks of Sen. Wilson), 516-17 (Rep. Eliot), 588-89 (Rep. Hubbard), 623, 632, 636-37 (Rep. Kelley), 652-53 (Rep. McKee) (1866).

69. For example, the bill was amended on January 22, 1866, to extend protection to Bureau officials. CONG. GLOBE, 39th Cong., 1st Sess. 348 (1866); see also id. at 516 (remarks of Rep. Eliot).

70. Senator Hendricks attacked sections 7 and 8 as overbroad and vague. Cong. GloBE, 39th Cong., lst Sess. 318 (1866).

71. Senator Davis stated that the "suits under this Freedmen's Bureau bill will be thick as leaves in Vallambrosa," id. at 417 , and raised the spectre of state clerks and judges being imprisoned for enforcing state laws, $i d$. at 418. 
state courts administered justice fairly and impartially. ${ }^{72}$ But he insisted that intervention should continue as long as was necessary to achieve this goal. ${ }^{73}$

Finally, and of particular importance here, Congress specifically and overwhelmingly rejected the concept of abstention during the debates on the Freedınen's Bureau bill. Senator Davis proposed an amendinent directing Bureau officials not to exercise any judicial powers in any State in which the laws could be enforced by the civil courts. ${ }^{74}$ The Senate rejected this aunendinent by a vote of $36-9 .{ }^{75}$ The Freedmen's Bureau bill passed both Houses overwhelmingly, ${ }^{76}$ but President Johnson vetoed it. ${ }^{77}$ The Senate was unable to override the veto, ${ }^{78}$ and a revised version was passed later in the session and became law on July $16,1866 . .^{79}$

72. Id. at $322-23,347$.

73. Id. at 322-23. Trumbull expected the federal courts to furnish protection under the provisions of the companion Civil Rights bill once the Bureau withdrew. Id.

Opponents of the Freedmen's Bureau bill raised some compelling constitutional arguments. Senator Davis considered the bill unconstitutional because it vested judicial power in officers of the executive branch. Id. at 415 . Proponents of the bill answered such arguments by citing the war powers and the enforcement provision of the thirteenth amendment. Id. at 319-23 (remarks of Sen. Trumbull), 631 (Rep. Moulton).

74. Id. at 399.

75. Id.

76. The bill passed the Senate $37-10$ on January 25 , id. at 421 , and the House $136-33$ on February 6, id. at 688.

77. The President's veto message of February 19, 1866, is set forth in E. MCPHERson, supra note 27 , at $68-72$.

78. The vote on the override attempt was 30-18. Cong. Globe, 39th Cong., 1st Sess. 943 (1866).

79. Freedmen's Bureau Act of 1866, ch. 200, 14 Stat. 173; see CoNG. Globe, 39th Cong., 1st Sess. app. 366-67 (1866). There were a number of differences between the original bill designed to extend Bureau protections and the revised bill that eventually became law. Some of these differences were: the term of the Bureau was reduced from a period of imdefinite duration, see $\mathrm{E}$. MCPherson, supra note 27, at 73, to a period of two years from the date of the bill's passage, 14 Stat. 173; the suggested size of the bureaueracy to administer Bureau affairs was decreascd, compare E. MCPHerson, supra note 27, at 73 with 14 Stat. 174; the language specifying the types of aid the Bureau could provide was made less imclusive, compare E. MCPHERSON, supra note 27, at 73 with 14 Stat. 174; and the civil rights to be protected were more specifically enumerated in the revised bill, 14 Stat. 176-77, presumably in response to the overbreadth and vagueness challengcs to the original provisions. See supra note 70; E. MCPherson, supra note 27, at 69 (President Johnson's veto message).

Finally, section 8 of the original bill, which would have subjected state and local officials to crimmal sanctions if they applied discrimimatory laws or facially neutral laws in discriminatory ways, see E. MCPHerson, supra note 27 , at 74, was completely dropped from the revised bill, along with the provisions investing Bureau officials with jurisdiction to hear such charges. By the time the revised bill was enacted in July, 1866, the companion Civil Rights bill had been passed over President Johnson's veto. See supra notes 77-79 and accompanying text. Because the Civil Rights Act provided crimimal sanctions for violations, under color of state law, of specifically enumerated civil rights and imvested the federal courts with jurisdiction to hear such cases, see 
(b). The Civil Rights Act. The provisions of Senator Trumbull's proposed Civil Rights bill complemented the Freedmen's Bureau bill. Section 1, in language that parallels section 7 of the Bureau bill, declared

that there shall be no discrimination in civil rights . . . on account of race . . . but the inhabitants of every race and color . . . shall have the same right to make and enforce contracts, to sue, be parties, and give evidence, . . . and to full and equal benefit of all laws and proceedings for the security of person and property, and shall be subject to like punishments, pains and penalties. ${ }^{80}$

Section 2 provided criminal penalties against any person who, under color of state law, denied another any right secured by the bill. ${ }^{81}$ Section 3 gave federal district courts exclusive jurisdiction over cases brought under section 2, and gave district and circuit courts concurrent jurisdiction "of all causes, civil and criminal, affecting persons who are demied or cannot enforce in the courts or judicial tribunals of the State or locality where they may be any of the rights secured to them by the act." 82 Section 3 also provided that any state suit, civil or criminal, commenced agaimst any such person, or against any officials carrying out the Civil Rights Act or the Freedmen's Bureau Act, could be removed to federal court. 83

These provisions contemplated substantial federal court intervention in the criminal and civil justice systems of the South to ensure fair and inpartial administration of the laws. ${ }^{84}$ Congress effectively told

infra notes $80-82$ and accompanying text, section 8 of the original Freedmen's Bureau bill was no longer necessary.

80. CONG. Globe, 39th Cong., 1st Sess. 211 (1866). Section 1 was subsequently anended to eliminate the first clause prohibiting "discrimination in civil rights." During the debate, various Senators criticized this general reference to civil rights as vague and overbroad. Id. at 477-78 (remarks of Sen. Saulsbury), 499 (Sen. Cowan), 1291 (Rep. Bingham); see Georgia v. Rachel, 384 U.S. 780, 791-92 (1965). House proponents felt that the specific enumeration of rights in section 1 was sufficient to achieve the bill's purpose and that the change would appease some House inembers. CONG. GloBE, 39th Cong., 1st Sess. 1366 (1866) (remarks of Rep. Wilson).

81. Cong. Globe, 39th Cong., 1st Sess. 211 (1866).

82. Id.

83. Id. In discussing section 3 , Senator Trumbull remarked:

[J]urisdiction is given to the Federal courts of a case affecting the person that is discriminated against. ... [l] $[$ [while] undertaking to enforce his right in a State court he was denied that right, then he could go into the Federal court; but it by no means follows that every person would have a right in the first instance to go to the Federal court.

Id. at 1759 . When section 3 was recodified in 1874 , the streainlined text provided only removal jurisdiction. Revised Statutes of 1874, $\$ 641$. See generally Ainsterdan, supra note 48, at 810-14. Sections 2 and 3 were enacted without substantial amendment. See Civil Rights Act of 1866, ch. 31, 14 Stat. 27.

84. See, e.g., Cong. Globe, 39th Cong., 1st Sess. 1153 (1866) (remarks of Rep. Thayer) ("The bill seeks to enforce these rights in the saine inanner and with the same sanctions under and by which other laws of the United States are enforced. It imposes duties upon the judicial tribu- 
southern officials that "all causes, civil and criminal," would be taken away from them by federal courts if defendants were denied fundamental rights in state proceedings. Moreover, during the debates, proponents of the Civil Rights Act made clear that it was to be broadly construed ${ }^{85}$ to combat the Black Codes and to remedy the unequal enforcement of the laws by southern justice officials. ${ }^{86}$ Opponents complamed that the bill would work wholesale reforin of state criminal codes, ${ }^{87}$ interfere with the duties of state judicial ${ }^{88}$ and executive ${ }^{89}$ officials, and result $\mathrm{m}$ a flood of petty cases being removed to federal court. ${ }^{90}$ Proponents of the measure answered that it was necessary because the judicial systems of the southern states routinely violated fundamental rights. ${ }^{91}$

Some legislators bitterly opposed possible imprisonment of state

nals of the country which require the enforcement of these rights."); see also id. at 605 (remarks of Sen. Trumbull).

85. See, e.g., id. at 211 (remarks of Sen. Trumbull) (The bill's purpose was "to protect all persons in the United States in their civil rights, and furnish the means of their vindication."), 1152 (Rep. Thayer) (The bill was to secure for freedmen "those rights which constitute the essence of freedom ...., those rights which secure life, liberty, and property, and which make all men equal before the law."); see also Jones v. Alfred H. Mayer Co., 392 U.S. 409, 420-44 (1968); CoNG. GlOBE, 39th Cong., 1st Sess. 1294 (1866) (remarks of Rep. Wilson).

86. See Cong. Globe, 39th Cong., 1st Sess. 474-75, 605, 1758-59 (remarks of Sen. Trumbull), 1267 (Rep. Raymond) (The Civil Rights bill "is intended to secure these citizens against imjustice that may be done them in the courts of the States withm which they may reside."), 504 (Sen. Howard), 602-03 (Sen. Lane), 603 (Sen. Wilson), 1118 (Rep. Wilson), 1123-25 (Rep. Cook), 1151-53 (Rep. Thayer), 1160 (Rep. Windom), 1263 (Rep. Broomall), 1833-35 (Rep. Lawrence) (1866); see also General Bldg. Contractors Ass'n v. Pennsylvania, 458 U.S. 375, 386-87 (1982).

87. See, e.g., Cono. Globe, 39th Cong., ist Sess. 598 (remarks of Sen. Davis) (Section 1 of the bill "breaks down all the penal laws that inflict punishment or penalty upon all the people of the States except so far as those laws shall be entirely uniform in their application."), 1293 (remarks of Rep. Bingham) (The bill proposes to "reform the whole civil and criminal code of every State government.") (1866); see also id. at 1777 (remarks of Sen. Johnson).

88. See, e.g., id. at 478, 480 (remarks of Sen. Saulsbury) (The bill assures "authority over the judicial tribunals in the administration of law in the States." In addition, "under [section 3] of the bill . . . the criminal jurisdiction of the courts of the States . . . is ousted."); see also id. at 1154 (remarks of Rep. Eldridge).

89. See, e.g., id. at 478 (remarks of Sen. Saulsbury), 598 (Sen. Davis), 1154 (Rep. Eldridge).

90. See, e.g., id. at 479 (remarks of Sen. Saulsbury), 1778 (Sen. Johnson).

91. See the remarks of Sen. Lane:

But why do we legislate upon this subject now? Simply because we fear and have reason to fear that the emancipated slaves would not have their rights in the courts of the slave States. ...

$\ldots .$.

Here is a justice of the peace in South Carolina or Georgia, or a county court, or a circuit court, that is called upon to execute this law. They appoint their own marshal, their deputy marshal, or their constable, and he calls upon the posse comitatus. Neither the judge, nor the jury, nor the officer as we believe is willing to execute the law.

Id. at 602-03; see also id. at 1124 (Rep. Cook) ("It is idle to say these nen will be protected by the states."), 1833-34 (Rep. Lawrence), 1265 (Rep. Broomall). 
judges under section 2 of the bill for simply enforcing state laws, ${ }^{92}$ but the proponents stood firm on this point. ${ }^{93}$ Senator Trumbull declared that if state judges exhibited the requisite intent to deny the rights set forth in section 1, or were guilty of criminal neghigence, then they could, and should, be sent to jail.94 The proponents of the bill also inade clear that whites as well as blacks were protected. ${ }^{95}$ Congress was especially concerned about the continuing violence against white loyalists and northern soldiers and the ongoing harassinent of these groups in the state courts. ${ }^{96}$

After long debate, both the House and Senate overwhelmingly approved the Civil Rights bill..$^{97}$ Nevertheless, President Johnson vetoed the bill, claiming that it intruded improperly into internal state affairs and authorized unprecedented federal court interference with officials in all branches of state government. ${ }^{98}$ The sponsors of the bill einphasized to Congress that the federal courts should interfere with state judicial and executive officials to the extent necessary to ensure impartial administration of justice..$^{99}$ Congress overrode the President's veto, and the Civil Rights bill becaine law on April 9, 1866. ${ }^{100}$

92. See, e.g., id. at 475, 500 (Sen. Cowan), 598 (Sen. Davis), 601-02 (Sen. Hendricks), 1121 (Rep. Rogers), 1154 (Rep. Eldridge), 1267 (Rep. Raymond), 1778 (Sen. Johnson).

93. On March 9, 1866, the House specifically rejected, by a vote of $113-37$, a proposed amendment offered by Representative Bingham which would have provided a civil cause of action rather than criminal sanctions against officials violating the Civil Rights Act. Id. at 1290-91, 1296.

94. Id. at 475, 1758; see id. at 1120 (remarks of Rep. Wilson); see also O'Shea v. Littleton, 414 U.S. 488, 503 (1974).

95. See, e.g., Cong. Globe, 39th Cong., 1st Sess. 598 (remarks of Sen. Davis), 599, 1758 (Sen. Trumbull), 1268 (Rep. Broomall), 1833 (Rep. Lawrence) (1866).

96. See, e.g., id. at 503 (remarks of Sen. Howard), 783 (Rep. Ward), 1263 (Rep. Broomall), 1617 (Rep. Moulton), 1629 (Rep. Hart), 1837-38 (Rep. Clarke), 1833 (Rep. Lawrence).

97. The Senate vote on February 2 was 33-12. CoNG. GlOBE, 39th Cong., 1st Sess. 606-07 (1866). The House vote on March 13 was 111-38. Id. at 1367. On March 15, the Senate adopted the House amendmeuts. Id. at 1413-16.

98. Id. at 1679-81 (President Johnson's veto message). The President was particularly alarmed at the prospect of large numbers of state court cases being removed to federal court. Id. at 1680 .

99. See id. at $1757-59$ (Sen. Trumbull's point by point response to the President).

100. The Senate voted to override 33-15 on April 6, id. at 1809; the House followed by a 12241 margin on April 9. Id. at 1861. Sections 1-3 of the Civil Rights Act have been carried forward to the present day. Section 1 is presently codified at 42 U.S.C. $\$ \S 1981-1982$ (1976); section 2 at 18 U.S.C. § 242 (1982); and section 3 at 28 U.S.C. § 1443 (1976).

Although the Supreme Court has recently acknowledged that the "principal object of the [1866 Act] was to eradicate the Black Codes," General Bldg. Contractors Ass'n v. Pennsylvania, 458 U.S. 375, 386 (1982), it has not recognized that Congress intended substantial federal court intervention in southern criminal and civil justice systems. Justice Marshall has observed that in the general climate of the Reconstruction era, the "1866 Civil Rights Act was not an isolated technical statute deahing with only a narrow subject. Instead, it was an integral part of a broad congressional scheme intended to work a major revolution in the prevaihing social order." General Bldg. Contractors Ass'n v. Pennsylvania, 458 U.S. 375, 409-10 (1982) (Marshall, J., dissent- 
(c). The May 11, 1866 Amendments to the 1863 Habeas Corpus and Removal Act. Congress's intent to use the federal courts for systemic reform of state criminal and civil justice is also evident from the debates on the bill to amend the Habeas Corpus and Removal Act of 1863.101 The 1863 Act $^{102}$ itself was directed at problems with the administration of justice in the South. Section 5 authorized persons subjected to state criminal or civil proceedings for acts done "under color of any authority derived from . . . the President of the United States" to file in the state proceeding a petition for removal to federal court. ${ }^{103}$ This provision had been enacted in response to vexatious state criminal and civil actions against northern soldiers for false arrest, trespass, and other mjuries. ${ }^{104}$ Once the petition and a bond were filed, the state court was to "proceed no further in the cause or prosecution." 105

In the spring of 1866 , Congress believed that amendments were necessary if the federal courts were successfully to "shield Army and Bureau officers from state court harassments [and] . . . block state judges from impeding operations of the national courts and laws." 106 During the debates the legislators complained that an alarming number of vexatious civil and criminal actions had been brought in state courts, ${ }^{107}$ and that southern judges were refusing to obey the 1863

ing) (footnote omitted). A fundamental part of that revolution was broad reform of southern justice.

101. The amending bill was reported in the House on March 13,1866 by Representative Cook. Cong. Globe, 39th Cong., Ist Sess. 1368 (1866). Senator Clark reported the bill in the Senate on April 4, 1866. Id. at 1753.

102. The measure was entitled "An Act relating to Habeas Corpus, and regulating Judicial Proceedings in Certain Cases." Act of Mar. 3, 1863, ch. 81, 12 Stat. 755.

103. Id. at 756.

104. See H. Hyman, A More Perfect Union 451-53; H. Hyman \& W. Wiecek, supra note 25 , at 259; Amsterdam, supra note 48, at 808-09 ("The debates on passage of this 1863 act reflect congressional concern that federal officers could not receive a fair trial in hostile state courts, and that ... appellate supervision ... would be madequate to rectify the decisions of lower state tribunals having the power to find the facts.").

105. Act of Mar. 3, 1863, ch. 81, 12 Stat 756. Section 5 even gave the parties the right to remove after final judgment was rendered, and to obtain in federal court either an appeal of the judgment or a trial de novo. Id. at 757. The Supreme Court subsequently held trial de novo unconstitutional im cases where the state verdict had been by jury. Justices v. Murray, 76 U.S. ( 9 Wall.) 274, 282 (1867).

106. H. HYMAN, supra note 104, at 471.

107. See, e.g., CONG. GloBE, 39th Cong., 1st Sess. 1526 (remarks of Rep. McKce) (complaining that in Kentucky 3500 suits by ex-rebels against federal officers and soldiers had been counted on the civil and criminal dockets), 1983 (Sen. Trumbull) (complaining that "several thousand suits" were pending agamst loyal men in Kentucky and other states), 2021 (Sen. Clark) (noting that as "the rebel soldiers and officers are returning to their hoines . . . thousands of suits are springing up all through the land, especially where the rebellion prevailed, against the loyal inen of the country who endeavored to put the rebellion down. . . . and these rebel courts are ready to decide against your Union men.") (1866). 
Act. ${ }^{108}$ Soine state courts had interpreted the 1863 Act to allow removal only when the defendant could produce an order froin the President. ${ }^{109}$ Section 1 of the 1866 bill clarified that any order by a superior officer was sufficient authority to warrant removal, and section 2 specified how such an order should be proved. 110 Some state courts also had interpreted the 1863 Act to limit severely the time im which a removal petition could be filed. ${ }^{11}$ Section 3 of the 1866 bill made clear that a petition could be filed at any time before a jury was empaneled. ${ }^{112}$

Fimally, in section 4 Congress attempted to put some teeth into the 1863 Act's direction that a state court should proceed no further once a proper removal petition was filed. Section 4 provided that "all such further proceedimgs shall be void . . . and all parties, judges, officers, and other persons, henceforth proceeding thereunder . . . shall be liable in damages therefor to the party aggrieved."113 A damage action could proceed in either state or federal court, and a successful plamtiff was entitled to double costs. ${ }^{114}$

The 1866 amendments to the 1863 Habeas Corpus and Removal Act reveal Congress's pervasive distrust of the state courts ${ }^{115}$ and its desire to ease the way for removal of thousands of cases to federal court. ${ }^{16}$ The aunending legislation easily passed both Houses; 117 Presi-

Harold Hyman notes that some northern officials had expected many damage actions to be filed against Army personnel as the war ended. "But apparently no one expected the post-Appomattox fiood to rise as swiftly and as high as it did." H. HYMAN, supra note 104, at 452.

108. See, e.g., CONG. Globe, 39th Cong., 1st sess. 2063 (remarks of Sen. Clark) ("I hold in my hand a communication from a member of the other House from Kentucky, in which he says that all the judicial districts of Kentucky, with the exception of one, are in the hands of sympathizing judges. They entirely disregard the act to which this is an amendment. They refuse to allow the transfer, and proceed agamst these men as if nothing had taken place."), 2063 (Sen. Stewart) (expressing fear that state judges would refuse to allow removal and arguing that state appellate remedies were inadequate), 2054 (Sen. Wilson), 2055 (Sen. Trumbull), 1880, 2054 (further reinarks of Sen. Clark) (1866).

109. See id. at 1387 (remarks of Rep. Cook).

110. Act of May 11, 1866, ch. 80, 14 Stat. 46.

111. See Cong. Globe, 39th Cong., Ist Sess. 1387-88 (1866) (remarks of Rep. Cook). Section 5 of the 1863 Act lent itself to restrictive imterpretation by stating that the defendant "shall" file the petition "at the time of entering his appearance in such court, or if such appearance shall have been entered before the passage of this act, then at the next session of the court in which such suit or prosecution is pending." Act of Mar. 3, 1863, ch. 81, 12 Stat. 756.

112. Act of May 11, 1866, ch. 80, 14 Stat. 46. Section 3 also continued the provisions for reınoval even after entry of final judgment. $I d$.

113. Id.

114. Id.

115. See Amsterdam, supra note 48 , at $823-25$.

116. See supra notes 107-08.

117. The measure passed the House 112-31 on March 20, 1866, CoNG. GLOBE, 39th Cong., 1st Sess. 1530 (1866), and with amendinents passed the Senate $30-4$ on April $20,1866, i d$. at 2066. A 
(d) The Fourteenth Amendment. While Congress was debating the Freedmen's Bureau and Civil Rights bills, the Joint Committee on Reconstruction, formed at the outset of the session, ${ }^{119}$ considered proposals for constitutional amendinents. ${ }^{120}$ Section 1 of the fourteenth amendment ${ }^{121}$ went through many drafts in the Joint Committee. ${ }^{122}$ The floor debates on the different drafts generally were conducted in lofty but vague terms. ${ }^{123}$ These debates contribute to the current ambiguity concerning precisely what deprivations of rights the fourteenth amendment empowers Congress to remedy. ${ }^{124}$

Whatever else section 1 may have been designed to correct, it is clear from the debates that the section was designed first and foremost to correct the immediate problems caused by the Black Codes and the maladministration of justice in the South. This is apparent from the language Representative Bingham chose to incorporate in section 1: "No State shall ... deprive any person of life, liberty, or property,

Conference Committee reachcd accord, $i d$. at 2303, and the Conference report was approved by both Houses, id. at 2330, 2383-84.

118. Act of May 11, 1866, ch. 80, 14 Stat. 46,47 .

119. See supra notes 64-118 and accompanying text.

120. Senator Davis noted that as of January 25,1866 , over 80 proposals to amend the Constitution were pending. CONG. GLOBE, 39th Cong., 1st Sess. 415 (1866). Four topics predominated: protecting the rights of citizens; apportioning seats in Congress; disqualifying former Confederates from holding federal office; and repudiating the rebel debt and validating the United States' debt. C. FAIRMAN, supra note 34, at 1261; see also 2 J. BLAINE, supra note 23, at 188-92; B. KENDRICK, supra note 51, at 266-67; J. Randall \& D. Donald, supra note 23, at 580-84. The Joint Committee formed subcoininittees to inquire into conditions in the southern states, B. KENDRICK, supra note 51 , at $47-48$, and these subcommittees conducted hearings interuittently between January and April, $1866, i d$. at 264 . Witnesses recounted continuing violence toward blacks and loyahists, the enactment of the Black Codes, and the maladministration of justice. Id. at 267-78.

121. Section 1 reads:

All persons born or naturalized in the United States, and subject to the jurisdiction thereof, are citizens of the United States and of the State wherein they reside. No State shall make or enforce any law which shall abridge the privileges or imınunities of citizens of the United States; nor shall any State deprive any person of life, liberty, or property without due process of law; nor deny to any person within its jurisdiction the equal protection of the laws.

U.S. CoNST. amend. XIV, \& 1.

122. See C. FAIRMAN, supra note 34, at 1270-74, 1281-83; Dimond, supra note 20, at 486-91.

123. See, e.g., CONG. GLOBE, 39th Cong., Ist Sess. 2542 (1866) (remarks of Rep. Bingham) (Section 1 would "protect by national law the privileges and imununities of all the citizens of the Republic and the inborn rights of every person within its jurisdiction whenever the same shall be abridged or denied by the unconstitutional acts of any State."); see also id. at 2766 (remarks of Sen. Howard). Many legislators made only brief inention of section 1. See, e.g., id. at 2465 (remarks of Rep. Thayer), 2510 (Rep. Miller), 2511 (Rep. Eliot). Sections 2, 3, and 4 apparently were more controversial. See C. FAlRMAN, supra note 34, at 1261.

124. See supra note 20; see also Bickel, supra note 12; Kaczorowski, Searching for the Intent of the Framers of the Fourteenth Amendment, 5 CONN. L. REv. 368 (1972-73). 
without due process of law; nor deny to any person within its jurisdiction the equal protection of the laws." I2s Deprivation of life or hiberty by a state typically occurs by pohce action or following a court proceeding. " "Due process of law," now, as then, "generally implies and includes actor, reus, judex, regular allegations, opportunity to answer, and a trial according to some settled course of judicial proceedings." 126 Similarly, denial of equal protection of the laws occurs when state legislators pass legislation that discriminates against a particular class, or when executive and judicial officials apply facially neutral laws in a discriminatory manner.

The legislators' comments on section 1 confirm this interpretation. Section 1 , in their view, would abohsh the Black Codes ${ }^{127}$ and enable Congress to pass legislation requiring states to administer justice fairly. ${ }^{128}$ Many inembers supported section 1 because they beheved it would "incorporate the guaranties of the Civil Rights Act of 1866 in the organic law of the land." 129 The frequent references to the Civil Rights Act in the debates on the fourteenth ainendment further strengthen the

125. U.S. Const. amend. XIV, $\S 1$.

126. Murray's Lessee v. Hoboken Land \& Improvement Co., 59 U.S. (18 How.) 272, 280 (1855). Raoul Berger has argued that historically, due process "related to judicial procedures prelimmary" to the deprivation of life or property. R. BERGER, supra note 12, at 195 (emphasis in origimal). He notes that

in virtually all of the State constitutions extant in 1866 the words "due process of law" .. . were . . . almost always found "in a section of the Constitution dealimg exclusively with the conduct of criminal trials, with the privileges of the accused, with a process in which the whole question is whether the person concerned shall be deprived of one or another of certain rights; that is of life, or personal hberty, or property as a penalty for a crime; and it is declared that he shall not, without due process."

Id. at 199-200 (emphasis in original) (quoting Shattuck, The True Meaning of the Term "Liberty" in Those Clauses in the Federal and State Constitutions Which Protect "Life, Liberty and Property," 4 HARv. L. REv. 365, 369 (1891)). It may reasonably be assumed, as Professor Berger asserts, that the lawyers who framed the Fourteenth Amendment undoubtedly were familiar with this association of due process and judicial procedures. Id. at 200.

127. See, e.g., CoNG. GlOBE, 39th Cong., 1st Sess. 1090 (remarks of Rep. Bingham), 2459 (Rep. Stevens), 2766 (Sen. Howard), 2961 (Sen. Poland), 3034 (Sen. Henderson) (1866).

128. See, for example, the remarks of Rep. Bingham, id. at 1064 (secures right for party aggrieved in his person to seek protection in the courts), 1090 (gives Congress power to punisl state officials for violation of their oaths to uphold the Constitution), 1094 (gives to everyone the right to "impartial, equal, exact justice"). See also id. at 2961 (remarks of Sen. Poland), 2082-83 (Rep. Perham), 2510-11 (Rep. Miller). Opponents of section 1 also recognized the power it extended to Congress to intrude into state affairs. See, e.g., id. at 1063-64 (remarks of Rep. Hale), 2081 (Rep. Nicholson), app. 134 (Rep. Rogers), 2500 (Rep. Shanklin), 2506 (Rep. Eldridge).

129. Hurd v. Hodge, 334 U.S. 24,32 (1948); see, e.g., CoNG. GlobE, 39th Cong., 1st Sess. 2465 (remarks of Rep. Thayer), 2498 (Rep. Broomall), 2283 (Rep. Latham) (1866). Senator Henderson complained that some state courts were holding the Civil Rights Act unconstitutional, thus necessitating its incorporation in the Constitution. Id. at 3035. Opponents also recognized this purpose of section 1. See, e.g., id. at 2538 (remarks of Rep. Rogers) (Section 1 "is no more nor less than an attempt to embody in the Constitution of the United States that outrageous and miserable civil rights bill."). 
conclusion that a primary purpose of section 1 was to empower Congress to reform state judicial-legal systems. ${ }^{130}$

The fourteenth amendment was not limited to discrimmation based on race. Echoing the Civil Rights Act debates, ${ }^{131}$ Congress expressed concern about continuing violence, discriminatory legislation, and harassment in southern courts directed at white loyahists and Union soldiers. ${ }^{132}$ Thus, denial of due process and equal protection, even for non-racial reasons, would provide grounds for congressional intervention. Moreover, Congress planned to designate the federal courts the chief enforcer of section 1.133 The fourteenth amendinent passed the House on May 10, 1866, ${ }^{134}$ and with amendments, was approved by the Senate on June 8.135 On June 13, the House concurred in the amendments and sent the measure to the states for ratification. ${ }^{136}$

Some legislators thought passage of the fourteenth amendment would resolve lingering doubts as to the constitutionality of the Civil Rights Act. See, e.g., id. at 2498 (remarks of Rep. Broomall), 2502, 2513 (Rep. Raymond), 2511 (Rep. Ehot), 3069 (Rep. Van Aernam). Others believed passage would prolibit a future Congress from repealing the measure should the Democrats gain control. See, e.g., id. at 2459 (remarks of Rep. Stevens), 2462 (Rep. Garfield), 2509 (Rep. Spalding), 2896 (Sen. Howard).

130. Thus the purpose was the same as that of the Civil Rights Act, namely to reform southern justice. See supra notes $80-100$ and accompanying text.

131. See supra notes $95-96$ and accompanying text.

132. See, e.g., Cong. Globe, 39th Cong., 1st Sess. 1065, 1091, 1093-94 (remarks of Rep. Bimgham), 1066 (Rep. Price), 2082 (Rep. Perham) (1866).

133. Id. at 1089-90 (remarks of Rep. Bingliam). The Supreme Court has repeatedly emphasized that the judiciary is to play a primary role in the protection of constitutional rights, including those riglits establislied by the fourteenth amendment. For example, in Davis v. Passman, 442 U.S. 228, 241 (1979), the Court stated that in the "great outlines" of the Constitution itself, "the judiciary is clearly discermible as the primary means tlırough which [constitutional] rights may be enforced." And in Bell v. Hood, 327 U.S. 678, 684 (1946), the Court held that "it is established practice for this Court to sustain the jurisdiction of federal courts to issue injunctions to protect rights safeguarded by the Constitution and to restrain individual state officers from doing what the 14th Amendment forbids the State to do." (footnotes omitted).

134. Cong. Globe, 39th Cong., 1st Sess. 2545 (1866).

135. Id at 3042. Section 1 was amended to add the first sentence: "All persons born or natu" ralized in the United States, and subject to the jurisdiction thereof, are citizens of the United States and of the State wherein they reside." $I d$. at 3040.

136. Id at 3149. Harold Hyman has asserted that Congress did not intend "a national monitoring system over state beliavior" in 1866 because the fourteenth amendment and the relatcd legislation "relied on mdividuals to secure their rights tlirouglı private case-by-case litigation" and "provided . . . unabrasive enforcers for use in the national courts." H. HYMAN, supra note 104, at 468. This view fails to appreciate the broad sweep and potential impact of the language Congress used in these various measures. The Freedmen's Bureau bill authorized Bureau officials to liear "all cases affecting negroes . . . or other persons who are discriminated agamst," see supra text accompanying note 66 (empliasis supplied), and the Civil Rights Act autlorized removal of "all causes, civil or criminal, affecting persons who are denied or cannot enforce" in local tribunals rights secured by the Act, see supra text accompanying note 82 (emphasis supplied).

Congress knew that the problems with the administration of justice were widespread and systemic. Thus, while mtervention was to be on a case-by-case basis, Congress contemplated that the number of cases involved would be enormous. Indeed, the May 11, 1866 amendments to the 
The Freedmen's Bureau bill, the Civil Rights Act, the May 11 Amendments to the 1863 Habeas Corpus and Removal Act, and the fourteenth amendment were the primary responses to the reconstruction problem in the first session of the Thirty-Ninth Congress. ${ }^{137}$ Congress adjourned without reaching agreement on what, if any, steps beyond ratification of the fourteenth amendment would be required to achieve readmission of southern representatives to Congress..$^{138}$

During the summer and fall of 1866, it became increasingly apparent that the South would defy Congress. The southern governmental structure put in place by President Johnson ${ }^{139}$ remained rebel-dominated and exclusively white. ${ }^{140}$ Violence agamst blacks, loyahists, and Umion soldiers contimued, ${ }^{141}$ as did discriminatory treatment of these

1863 Habeas Corpus and Removal Act were intended to facilitate the removal of thousands of cases from state to federal court. See supra notes 106-16 and accompanying text. The federal courts can hardly be described as "unabrasive enforcers" of federal rights, if, as Congress intended, a substantial proportion of state litigation was to be unceremoniously wrenched froin the state courts.

During the ratification debate on the fourteenth amendment, opponents understood that Congress intended "a national monitoring systein over state behavior" in general and over the behavior of state judges in particular. For example, Interior Secretary Browning wrote a letter that appeared in The Cincinnati Commercial severely criticizing the amendinent on those grounds:

"The object and purpose are manifest. It is to subordinate the State judiciaries in all things to Federal supervision and control; to totally annihilate the independence and sovereignty of State judiciaries in the administration of State laws. . . [B]y virtue of this new provision, if adopted, every matter of judicial investigation, civil or criminal, however insignificant, may be drawn into the vortex of the Federal judiciary."

Nowak, The Scope of Congressional Power to Create Causes of Action Against State Governments and the History of the Eleventh and Fourteenth Amendments, 75 CoLUM. L. REv. 1413, 1457 (1975) (quoting Cincinnati Commercial, Oct. 26, 1866, at 2, col. 4).

137. Congress passed additional measures aimed at the inaladministration of justice in the South. The Separable Controversies Act, ch. 288, 14 Stat. 306 (1866), was enacted to curb the southern state court practice of allowing local plaintiffs to jom local defendants in suits against citizens of the North, thus destroying complete diversity and blocking removal to federal court. H. HYMAN, supra note 104, at 472. The Act allowed a nonresident defendant to reinove his portion of the case to federal court, leaving the claims against the resident defendant for adjudication in the state court. Separable Controversies Act, ch. 288, 14 Stat. 306 (1866). Yet another statute allowed federal revenue agents to remove state suits to federal court. Internal Revenue Act of July 13, 1866, ch. 182, 14 Stat. 98, 171. Harold Hyinan sees in these enactments the "symbiotic relationships growing between Congress and the national courts, in which the latter served the nation as the prinary executor of federal law." H. HYMAN, supra note 104, at 472. 38.

138. See generally C. FAIRMAN, supra note 34, at 262-64; B. KENDRICK, supra note 51, at 327-

139. See supra notes 23-27 and accompanying text.

140. See C. Fairman, supra note 34, at 258; see also Cong. Globe, 39th Cong., 2d Sess. app. 33 (1866) (report of Major General Jeff C. Davis citing rebel pohitical control in Kentucky).

141. See CONG. GLOBE, 39th Cong., 2nd Sess. app. 33 (report of General Jeff C. Davis), app. 35 (report of General D.E. Sickles) (1866); 2 J. BLAINE, supra note 23, at 233-35; J. RANDALL \& D. DONALD, supra note 23, at 587. 
groups by southern justice systems. ${ }^{142}$ Officers of the Freedmen's Bureau and the army tried to cope with these problems, ${ }^{143}$ but "the mass of southern opinion was hardening against cooperation; indeed, it was becoming overtly hostile toward the federal presence."144 The Civil Rights Act proved ineffective in enforeing fair treatment in southern courts. ${ }^{145}$ And, as the final straw, southern state legislatures refused to ratify the fourteenth ainendment. ${ }^{146}$

3. Congressional Reconstruction from 1867-1870. Fresh from a triumph in the 1866 elections, ${ }^{147}$ Republicans were in an assertive and angry mood when the second session of the Thirty-Ninth Congress convened. ${ }^{148}$ The legislators complaimed about the continumg violence

142. Reports of Union military personnel presented a mixed picture of the administration of justice. General Sheridan reported: "My own opinion is that the trial of a white inan for the inurder of a freedman in Texas would be a farce, and in inaking this statement I make it because truth compels ine, and for no other reason." Cong. Globe, 39tli Cong., 2nd Sess. app. 30 (1866). General Thoinas J. Wood reported that "substantial justice is now adninistered throughout [Mississippi] by the local judicial tribunals," but he acknowledged that "niany outrages and crincs" have gone unpumished. Id. at app. 32. General D.E. Sickles reported front South Carohna that "[w]hen arrests are made by military authority and the parties turned over to civil tribunals, the accused are generally admitted to easy bail." Id. at app. 35 .

143. The Freedmen's Bureau received nore than I00,000 complaints in 1866. H. HYMAN \& W. WIECEK, supra note 25 , at 420 . The reports of the inilitary personnel describe the army's response. See Cong. Globe, 39th Cong., 2nd Sess. app. 30-37 (I866).

144. H. HYMan \& W. Wiecek, supra note 25, at 420.

145. S.C. Gardner, an Alabama Freedinen's Bureau officer, explamed why the Civil Rights Act was not working in a letter to Senator Charles Sumner:

[R]ecourse to the federal district or circuit courts under the Civil Rights Law was ". . . too cumbersoine for the effect. It is like using the Great Eastern [the world's largest ship] for a ferry-boat. It is remote and infrequent, and lomeless complainants [who] are compelled to get a livelihood where they can, often drift out of reach and knowledge. The saine is true of witnesses."

H. HYMAN \& W. WIECEK, supra note 25, at 424 (quoting letter of Nov. 19, 1866). Hyman and Wiecek conclude: "The Civil Rights law was failing where it counted most, in local communities and neighborhoods; failing less due to formal denials of civil rights by state officcrs of high visibility than by almost invisible, scattered, low-rank local officials who adininistered state laws and community justice." Id. at 425; see also Soifer, supra note 20, at 688-89.

146. See C. Fairman, supra note 34, at 254.

147. In the Fortietl Congress, which convened the following March, the Republicans had majorities of almost three to one in the House and almost four to one in the Senate. C. FAIRMAN, supra note 34, at I82. The Republican victory was seen as a repudiation of the President's pohicies and a signal to Congress to continue to address the Reconstruction problem vigorously. $2 \mathrm{~J}$. BLAINE, supra note 23, at 246, 250.

148. See 2 J. BLAiNE, supra note 23, at 246-50; C. FAIRMAN, supra note 34, at 253-57; B. KENDRICK, supra note 51, at 354-57. Nunerous bills and resolutions calling for the dismantling of the Jolinson governments in the South or for enfranchisenient of blacks were introduced at the outset of the session. B. KeNDRICK, supra note 51, at 355-56; see, e.g., CONG. GlOBE, 39tl Cong. 2d Sess. 11, 15, 211 (1866). 
directed against blacks and loyahists, ${ }^{149}$ the general lack of security of hife and property, ${ }^{150}$ and the widespread breakdown of southern justice. ${ }^{151}$ Ultimately, Congress decided that drastic ineasures were required to deal with these problems. The Military Reconstruction Act of March 2, 1867, sent the Army "to guaranty present protection and equal justice." 152 To secure readmission of their representatives to Congress, the rebel states were required to form new governments, grant impartial suffrage, and ratify the fourteenth ainendinent. ${ }^{153}$ In

149. Complaints of violence appear repeatedly throughout the first 1500 pages of the record of the session. For examples, see CoNG. GLOBE, 39th Cong., 2d Sess. 154, 251, 255, 349, 536, 560, $594,628,1104,1178-79,1186-87,1375-77,1462$ (1866-67). Numerous speakers cited the race riots in Memphis and New Orleans, see, e.g., id. at 351 (Rep. Broomall), 28-29 (Rep. Ehot), 1175 (Rep. Shellabarger), 1178 (Rep. Kelley), 1633 (Sen. Howe), and some noted the complicity of southern officials in the slaughter of blacks, see, e.g., id. at 351 (Rep. Broomall), 1175 (Rep. Shellabarger), 1633 (Sen. Howe).

150. See, e.g., id. at 211 (Sen. Ross), 160 (Sen. Trnmbull), 349 (Rep. Broomall), 1083 (Rep. Lawrence), 1101 (Rep. Rayinond), 1181 (Rep. Allison), 1210 (Rep. Boutwell).

151. Speakers noted that the Black Codes often contmued in force, and that facially neutral laws were administered im a discriminatory manner. See, e.g., id. at 16 (remarks of Sen. Sumner), 153-54 (Reps. Stevens and Schenck), 1179 (Rep. Kelley), 1632 (Sen. Howe).

Virtually all southern justice officials were criticized for refusing to administer the law fairly, including sheriffs and constables, jailors, grand jurors, petit jurors, and judges. See id. at 160, 255, 560, 1101, 1179, 1187, 1370-71, 1567-69, 1631, app. 94-95, app. 99-100, app. 161. The Civil Rights Act, some noted, had been meffective in achieving the sort of systemic reform Congress sought. See id. at 1367 (Sen. Morrill), 1370-71 (Sen. Henderson), 1375-76 (Sen. Wilson).

The extent of Congressional frustration over the maladmimistration of justice in the South, and particularly over the conduct of southern judges, is indicated by the proposal offered by Representative Lawrence on February 7, 1867: "[T]he district courts of the United States [in the rebel states] . . . shall have power and jurisdiction . . . to hear and determine all causes, proceedings, and rights of action at law, in equity, and all matters of probate and testamentary jurisdiction as fully" as the state courts could hear such matters before the war. Id. at 1084. He also proposed that the criminal laws of the District of Columbia "shall be in force" in the rebel states, and that prosecutions for alleged violation of these laws would likewise be heard in the federal courts. Id. Lawrence's proposal extended the subject matter jurisdiction of the federal courts well beyond Article $11 \mathrm{l}$ limits; indeed, he appeared to contemplate replacement of the state courts by the federal courts. His proposals were not adopted.

152. Id. at 1098 (remarks of Rep. Thayer). The Mihtary Reconstruction Act, ch. 153, 14 Stat. 428 (1867), passed over President Johnson's veto, CoNG. GLOBE, 39th Cong., 2d Sess. 1976 (1867), was modestly titled "An Act to provide for the more efficient Government of the Rebel States." It declared that "[w]hereas no legal State goveriments or adequate protection for life or property now exists in the rebel States," the states were to be divided imto five military districts. Military Reconstruction Act, ch. 153, 14 Stat. 428 (1867). The commanding officer of each district was assigned the duty "to protect all persons in their rights of person and property" and to "suppress ... violence." Id. In addition, he was authorized to try all offenders before inihtary tribunals when in his judgment the local courts were madequate. Id.

153. The readmission process had several steps. First, each rebel state was required to form a new constitution. Delegates to the state constitutional convention were to be elected by all adult males, black and white, except for those persons disqualified by section 3 of the fourteenth amendinent. The constitution had to provide for impartial suffrage and be approved by a majority of persons voting on its ratification. The constitution also had to be examined and approved by Congress. Fimally, the state legislators elected under the new constitution were required to ratify 
addition, Congress passed legislation further increasing the role of the federal courts in monitoring southern justice. ${ }^{154}$

Despite attempts to circuinvent the provisions of the congressional enactments, ${ }^{155}$ the South had little choice but to follow Congress's directions. ${ }^{156}$ The fourteenth ainendinent was ratified by most soutliern

the fourteenth amendment. Mihtary occupation would cease when these requirements were met and the fourteenth amendment became effective. Mihtary Reconstruction Act, ch. 153, 14 Stat. 428, 429 (1867). For detailed accounts of the Military Reconstruction Act's passage through Congress, see C. FAIRMAN, supra note 34, at 285-309; B. KENDRICK, supra note 51, at 358-414.

154. On February 5, 1867, Congress enacted two amendments to the Judiciary Act of 1789. One allowed federal courts to issue writs of habeas corpus in "all cases where any person may be restramed of his or her liberty in violation of the constitution, or of any treaty or law of the United States." Habeas Corpus Act of 1867, ch. 28, 14 Stat. 385. The other amendment eliminated language in section 25 of the Judiciary Act of 1789 restricting the Supreme Court to consideration of federal questions in reviewing state court decisions on writ of error. Id. at 386-87.

The limited Congressional debate makes clear that Congress intended the habeas corpus amendment to empower federal courts to reach persons held in state custody in violation of federal law, and that the measure should be broadly construed. See, e.g., CoNG. GLOBE, 39th Cong., Ist Sess. 4230 (remarks of Sen. Trumbull), 4151 (Rep. Lawrence) (1867). Some scholars have questioned the intended scope of this provision. See Fay v. Noia, 372 U.S. 391,436 (1963). Compare Mayers, The Habeas Corpus Act of 1867: The Supreme Court as Legal Historian, 33 U. CHI. L. REv. 31 (1965), with Ainsterdam, supra note 48, at 819-23.

The second of these amendinents on its face greatly expanded the Supreme Court's appellate jurisdiction by opening all issues in a case to that Court's review. As Charles Alan Wright has argued, it "seems entirely plausible that Congress intended by eliminating the proviso to open the whole case for review by the Supreme Court, if there is a federal question in the case sufficient to take the case to the Supreme Court." C. WRIGHT, LAW of FEDERAL CourTs 746 (1983). Professor Wright is plainly correct in noting that "[s]uch a course seems wholly consistent with the temper of the times." Id. The amendment was consistent with the power extended to the lower federal courts to hear state law issues in cases removed to federal court beeause the state courts discriminated. Nonetheless, the Supreme Court rejected this interpretation and held that the anendment worked no change in the Court's appellate jurisdiction. Murdock v. Memphis, 87 U.S. (20 Wall.) 590 (1875). Anthony Amsterdain has commented on the Murdock holding:

I have serious doubts (as did the Justices) whether the result in that case was purposed by

Congress; and this very doubt whether Congress might not have meant to turn Supreme

Court review into a sort of post hoc removal suggests the extreme disfavor in which the

Thirty-ninth Congress held the state courts.

Amsterdam, supra note 48, at 819 n.111.

In addition, the 1863 Habeas Corpus and Removal Act was amended on February 5, 1867. If a case was removable from state to federal court under the 1863 Act (or under the Act as amended in 1866) and a state judge refused to release from state custody the party seeking removal, a federal court could compel his release by habeas corpus. Act of Feb. 5, 1867, ch. 28, 14 Stat. 385.

Congress also amended the Separable Controversies Act, ch. 288, 14 Stat. 306 (1866), see supra note 137. This amendment allowed nonresident plaintiffs, as well as defendants, to reinove the portion of a suit involving diversity of citizenship to federal court. Moreover, removal was authorized upon an affidavit stating that the party "has reason to and does believe that, from prejudice or local imfluence, he will not be able to obtain justice in such State court." Act of Mar. 2, 1867, ch. 196, § 1, 14 Stat. 558, 559.

155. See C. FalRman, supra note 34, at 404-29.

156. Registration of voters took place in late summer and early autunin of 1867 , and constitutional conventions were held in the late fall of that year and in the early spring of $1868.1 d$. at 89 , 433. Constitutions were formed and approved and legislatures elected. $2 \mathrm{~J}$. BLAINE, supra note 23, 
states and became effective July 28, 1868.157 By that date, only Georgia, Mississippi, Virginia, and Texas had not gained readmission of their representatives to Congress. ${ }^{158}$ By the spring of 1870 , every state's representatives had secured readinission to Congress. ${ }^{159}$

4. Congressional Action in the Spring of 1871. As Reconstruction of the southern states was completed, military control was withdrawn. ${ }^{160}$ For most southern whites, however, "there was really no intention to acquiesce in the legislation of Congress, no purpose to abide by the Constitutional Amendments in good faith."161 The $\mathrm{Ku}$ Klux Klan and sinilar groups spread terror in an organized and systematic manner ${ }^{162}$ while southern criminal justice officials turned a deaf ear to the victinus' complaints. ${ }^{163}$ Congress responded by passing the Civil Rights Act of April 20, 1871.164

at 300; Developments in the Law-Seetion 1983 and Federalism, 90 HARv. L. REv. 1133, 1146-47 (1977). Blacks exercised their right to vote in these elections. C. FAlRMAN, supra note 34, at 40529.

157. 2 J. BLAINE, supra note 23 , at 309.

158. J. RANDALl \& D. Donald, supra note 23, at 619.

159. Id. at 619-22; see also $2 \mathrm{~J}$. BLAINE, supra note 23, at 463-64.

160. $2 \mathrm{~J}$. BlalNe, supra note 23 , at 466.

161. 2 id. at 467.

162. See 2 id. at 469-70; J. Randall \& D. DonAlD, supra note 23, at 682-84. See generally D. Chambers, Hooded Americanism: The History of THE KU KiUX KLAN (1965).

163. See infra notes $170-77$ and accompanying text.

164. Ch. 22, 17 Stat. 13 (1871). Congress also enacted a ineasure on February 28, 1871, augmenting an Act passed May 31, 1870, which protected the right of blacks to vote under the fifteenth amendment. The 1870 Act required state election officials to apply voter registration requirements impartially, and prohibited any person froin using force or intimidation to obstruct registration or voting. Civil Rights Act of 1870 , ch. 114, $\S 1-6,16$ Stat. 140, 141. The federal courts were given exclusive jurisdiction over all actions, civil and criminal, brought under the Act. Civil Rights Act of 1870, ch. 114, $\S 8,16$ Stat. 140, 142. The 1870 Act also reenacted the Civil Rights Act of 1866. Civil Rights Act of 1870, ch. 114, $\$ 18,16$ Stat. 140, 144, pursuant to the fourteenth amendment, CoNG. GlOBE, 41 st Cong., 2d Sess. 3701 (1870) (reinarks of Sen. Stewart), and broadened that legislation's coverage to include aliens. See Chapman v. Houston Welfare Rights Org., 441 U.S. 600, 628 n.6 (1979) (Powell, J., concurring); United States v. Classic, 313 U.S. 299, 327 n.10 (1941).

The February 28, 1871 annendmeuts to the 1870 Act gave the federal courts a central role in enforcing the legislation. Congress einpowered the federal courts to appoint election supervisors who in turn received broad powers to regulate election procedures. Act of Feb. 28, 1871, ch. 99, $\$ \$ 1-6,16$ Stat. 433, 433-35. The amendments also imposed duties on federal marshals to assist in preventing intimidation or violence at the polls. Act of Feb. 28, 1871, ch. 99, \$ 8, 16 Stat. 433, 436. Crimimal sanctions were provided for interference with the supervisors or marshals, id. $\S 10,16$ Stat. 433, 436-37, and offenders were to be tried in federal court. Act of Feb. 28, 1871, ch. 99, §9, 16 Stat. 433,436 . In addition, the amendments created a private right of action in federal court for damages or injunctive rehef against persons violating its provisions. $I d . \S 15,16 \mathrm{Stat} .433,438$. Finally, if federal officials or private persons were subjected to civil or criminal actions in a state court for enforcing the provisions of the Act or exercising their rights under it, the cases could be removed to federal court. Id. $\S 16,16$ Stat. $433,438-39$. 
Section 1 of the Civil Rights Act created a private right of action for damages or equitable relief agamst persons actimg under color of state law who deprived someone of rights secured by federal law, and gave the federal courts jurisdiction to entertain such actions. ${ }^{165}$ Other provisions provided damage remedies and criminal sanctions against persons conspiring to deprive another person of constitutional rights, ${ }^{166}$ authorized the President to suspend habeas corpus ${ }^{167}$ and to send the army to establish order, ${ }^{168}$ and disqualified former Confederates from jury service. 169

The Civil Rights Act consumed nearly all of the attention of the first session of the Forty-Second Congress. Numerous legislators called

\begin{abstract}
165. Section 1 of the Act reads as follows:
Be it enacted by the Senate and House of Representatives of the United States of America in Congress assembled, That any person who, under color of any law, statute, ordinance, regulation, custom, or usage of any State, shall subject, or cause to be subjected, any person within the jurisdiction of the United States to the deprivation of any rights, privileges, or immunities secured by the Constitution of the United States, shall, any such law, statute, ordinance, regulation, custom, or usage of the State to the contrary notwithstanding, be liable to the party injured in an action at law, suit in equity, or other proper proceeding for redress; such proceeding to be prosecuted in the several district or circuit courts of the United States, with and subject to the same rights of appeal, review upon error, and other remedies provided in like cases in such courts, under the provisions of the act of the ninth of April, eighteen hundred and sixty-six, entitled "An act to protect all persons in the United States in their civil rights, and to furnish the means of their vindication"; and the other remedial laws of the United States which are in their nature applicable in such cases.
\end{abstract}

Civil Rights Act of 1871, ch. 22, § 1, 17 Stat. 13.

The provisions of section 1 as presently codified read in pertiment part:

Every person who, under color of any statute, ordinance, regulation, custom, or usage, of any State or Territory, or of the District of Colunubia subjects, or causes to be subjected, any citizen of the United States or other person within the jurisdiction thereof to the deprivation of any rights, privileges, or immunities secured by the Constitution and laws, shall be liable to the party injured in an action at law, suit in equity, or other proper proceeding for redress.

42 U.S.C. \& 1983 (Supp. V 1981).

The district courts shall have original jurisdiction of any civil action authorized by law to be commenced by any person: ... .

(3) To redress the deprivation, under color of any State law, statute, ordinance, regulation, custoun or usage, of any right, privilege or immunity secured by the Constitution of the United States or by any Act of Congress providing for equal rights of citizens or of all persons within the jurisdiction of the United States... . .

28 U.S.C. \& 1343(3) (Supp. V 1981).

166. Civil Rights Act of 1871, ch. 22, § 2, 17 Stat. 13, 13-14 (section 2) (presently codified at 42 U.S.C. \& 1985 (Supp. V 1981)). The federal courts were given jurisdiction of such cases. Civil Rights Act of 1871, ch. 22, \& 2, 17 Stat. 13, 14. Section 6 of the Act (presently codified at 42 U.S.C. $\S 1986$ (1976)) created a cause of action for danages against persons who had the power to prevent violations of section 2 but failed to do so, and gave the federal courts jurisdiction over such actions. Civil Rights Act of 1871, ch. 22, §6, 17 Stat. 13, 15.

167. Civil Rights Act of 1871 , ch. $22, \S 4,17$ Stat. 13, 15.

168. Id. \& 3, 17 Stat. 13,14 .

169. Id. , \& 5, 17 Stat. $13,15$. 
Congress's attention to the substantial evidence of Klan violence, ${ }^{170}$ and repeated familiar complaints concerning the widespread, systemic breakdown in the administration of southern justice. ${ }^{171}$ Southern laws, although typically not discriminatory on their face, continued to be apphed unequally. ${ }^{172}$ Legislators registered specific complaints concerning virtually all components of the justice system. They protested that southern sheriffs refused to serve writs properly or to imvestigate allegations of crime and arrest offenders. ${ }^{173}$ Grand jurors often refused to indict, and when indictments did occur, petit jurors refused to convict. ${ }^{174}$ Witnesses regularly committed perjury or refused to testify. ${ }^{175}$ Judges abused their bail-setting powers, ${ }^{176}$ and refused or failed to admimister justice impartially. ${ }^{177}$

The debates also reveal that most legislators believed that the Constitution provided Congress witl ample power to correct these

170. See, e.g., Cong. Globe, 42d Cong., 1st Sess. app. 30-36 (remarks of Sen. Scott), 152-60 (Sen. Sherman), 236-40 (Sen. Morton), 442-48, 490 (Rep. Butler), app. 190-96 (Rep. Buckley), app. 196-203 (Rep. Snyder), app. 283-99 (Sen. Stevenson) (1871). Dozens of others registered the same complaint. Congress had before it a report of almost 600 pages concerning Klan violence. S. REP. No. 1, 42d Cong., 1st Sess. (1871). Many legislators recited the testimony in the report during the debates.

171. For examples of general complaints of official failure to administer justice fairly and to convict or punish those who violated the constitutional rights of others, see CONG. GLOBE, 42d Cong., 1st Sess. 197, 201, 369-70, 374, 428, 444, 459, 483, 502, 505, 608, 653-54, 665, and at app. 72, $78,108,147,185,190,198,252,281,312$. Many legislators accused sonthern officials of either belonging to the Ku Klux Klan or being in complicity with it. See, e.g., id. at app. 72 (remarks of Sen. Blair) (asserting that some southern sheriffs belonged to the Klan), 445 (Rep. Butler) (asserting that the Tennessee legislature was in collusion with the Klan); see also id. at 476 (Rep. Dawes), 608, app. 172 (Sen. Pool), 506 (Sen. Pratt), app. 183 (Rep. Platt), app. 201 (Rep. Snyder).

172. See, e.g., id. at app. 300 (remarks of Sen. Stevenson) ("Unexecuted laws are no "protection.' And this brings us to the very case: the states have laws providing for equal protection, but they do not, because either they will not or cannot, enforce them equally; and hence a class of citizens have not 'the protection of the laws.' "), app. 153 (Rep. Garfeld), 277 (Rep. Porter), 333 (Rep. Hoar), 505-06 (Sen. Pratt).

173. See, e.g., id. at app. 78 (remarks of Rep. Perry) ("sheriffs, having eyes to see, see not"), 334 (Rep. Hoar), 459 (Rep. Coburn), app. 185 (Rep. Platt).

174. Specific complaints of misconduct of jurors also can be found. Id. at 155, 157-58, 201, $334,429,458,481,487,502$, and at app. 108, 172, 182, 193, 197-98, 252, and 270.

175. See, e.g., id. at 201, 437, 458, 481, 502, 571, 653, and at app. 182, 199, 252, 270, 310.

176. See, e.g., id. at 155 (remarks of Sen. Sherman) (recounting testimony of southern newspaper editor that any persons charged with the murder of blacks were released on "straw bail"), 571 (remarks of Sen. Ames) (asserting that persons eharged with murdering blacks were released on only one hundred to five hundred dollars bail).

177. See, e.g., id. at 394 (remarks of Rep. Ramey) (The "courts are in many instances under the control of those who are wholly inimical to the impartial administration of law and equity."), app. 185 (remarks of Rep. Platt) ("[N]o Republican, white or black, especially if he is a citizen who has come here from another State or is at all prominent, can secure as plaintiff or defendant anything like equal justice before the courts of [Virginia]."), app. 78 (remarks of Rep. Perry) ("judges, having ears to hear, hear not"); see also id. at 201 (Sen. Nye), 321 (Rep. Stoughton), 482 (Rep. Wilson), 487 (Rep. Lansing), 653 (Sen. Osborn), app. 251 (Sen. Morton), 429 (Rep. Beatty). 
problems. For some members of Congress, the equation was simple. The highest duty of government, they asserted, was to protect the citizenry from violence and injustice, ${ }^{178}$ and the Constitution conferred a general power upon Congress to act to protect life, liberty and property. ${ }^{179}$ Most of the legislators, however, relied specifically upon the first and fifth sections of the fourteenth amendment for the power to enforce constitutional rights. ${ }^{180}$

178. See, e.g., id. at 427 (remarks of Rep. McKee); see also id. at 201 (Sen. Nye), 208 (Sen. Sawyer), 367 (Rep. Sheldon), 439 (Rep. Cobb), app. 141 (Rep. Shanks).

179. See, e.g., id. at 370 (remarks of Rep. Monroe) ("In interpreting the constitution of any great, free country there is a fair presumption that it contains sufficient grants of power to the legislative body to secure the great primal objects for which constitutions and Governments exist. . . . We feel that we ought to find in such an instrument protection for the people."); see also id. at 374-75 (Rep. Lowe), 475-76 (Rep. Dawes), 487 (Rep. Lansing), 511 (Rep. Perce), app. 228 (Sen. Boreman).

180. See, e.g., id. at 322 (remarks of Rep. Stoughton), app. 83 (Rep. Binghan), 375 (Rep. Lowe), 390 (Rep. Elliott), 428 (Rep. Beatty), 448 (Rep. Butler), 504-06 (Sen. Pratt), 608-09 (Sen. Pool), app. 182 (Rep. Mercur), app. 229 (Sen. Boreman), app. 256 (Sen. Wilson), app. 262 (Rep. Dunnell), app. 299-300 (Sen. Stevenson).

Representative Wilson traced this argument with particular care. He believed that the prohibitions of the fourteenth amendment reached broadly to all branches of state government. "Obvionsly the word [State] is used in its largest and most comprehensive sense. 11 means the government of the State. What is a State in its true sense? . . [ [1]t is a trinity: the legislative, the judicial, and the executive; these three are one, the State." Id. at 482; see also id. at 506 (remarks of Sen. Pratt), app. 182 (Rep. Mercur), 607 (Sen. Pool), app. 315 (Rep. Burchard), 696 (Sen. Edmunds). Thus, Wilson argued, the words "No State shall deny to any person within its jurisdiction the equal protection of the laws" did not apply solely to legislative enactments which discrimimated on their face. Instead, the fourteenth amendment also prohibited unequal enforcement or execution of the laws by state judicial and executive officials:

But it is argued that this word "deny" only means that a State shall not affirmatively by statutory enactment discrimmate between persons subject to its jurisdiction. . . . But ... this language cannot fairly or reasonably be construed to refer exclusively to denial by statutory enactment. If such had been the meaning the language would have been "no law shall be enacted," or "no legislature shall enact," etc., indicating in explicit terms that it was a statutory denial that was meant.

Id. at 482; see also id. at app. 153 (Rep. Garfield), app. 182 (Rep. Mercur), app. 300 (Sen. Stevenson), 697 (Sen. Edmunds), 459 (Rep. Coburn).

Moreover, in Wilson's view, neglect or failure of state officials to perforn their constitutional duties constituted a demial of equal protection:

[W] hen it is provided that no State shall deny to any person the equal protection of the laws it certainly is meant and it is equivalent to a provision that all citizens shall be equally protected. The word "deny," therefore, as here used, must be construed with reference to the spirit of the whole instrument. It is equivalent to the phrase "fail or refuse to provide for".

Id. at 482. Other legislators agreed with this interpretation of the fourteenth amendment. See, e.g., id. at 501 (remarks of Sen. Frelinghuysen) ("A State denies equal protection whenever it fails to give it. Denying imcludes maction as well as action. A State denies protection as effectively by not executing as by not making laws."); see also id. at 334 (Rep. Hoar), app. 80 (Rep. Perry), 251 (Sen. Morton), app. 300 (Sen. Stevenson), app. 315 (Rep. Burchard), 459 (Rep. Coburn), 697 (Sen. Edmunds). Based on Wilson's reasoning, Representative Burchard concluded that Congress could require state officials to perform their duties:

[Congress] may doubtless require State officers to discharge duties imposed upon thein as such officers by the Constitution of the United States. ... [T] [The officer who violates his 
Congress's broad construction of its enforcement powers during the debate on the Civil Rights Act suggests that Congress meant to create a broad remedy in section 1 of the Act. ${ }^{181}$ The civil remedy in the federal courts against any person who, under color of state law, deprived another of federal rights could extend to state officials in all branches of state government. It could reach the neglect or failure of criminal and civil justice officials to perform constitutional duties. ${ }^{182}$ The federal courts could require those officials to discharge their duties.

This interpretation of the scope of the civil remedy is given explicit support in congressional statements about "how the courts would and should interpret $§ 1 . " 183$ Representative Shellabarger, who introduced the legislation, stressed that it should be broadly construed:

This act is remedial, and in aid of the preservation of human liberty and human rights. All statutes and constitutional provisions authorizing such statutes are liberally and beneficially construed. It would be most strange and, in civilized law, monstrous were this not the rule of interpretation. As has been again and again decided by your own Supreme Court of the United States ... . the largest latitude consistent with the words employed is uniformly given in construing such statutes and constitutional provisions as are ineant to protect and defend and give remedies for their wrongs to all the people. ${ }^{184}$ Representative Dawes envisioned vigorous federal court enforcement of section 1 remedies:

$[\mathrm{H}] \mathrm{e}$, sir, who imvades, trenches upon, or impairs one iota or title of the least of [constitutional guaranties] to that extent trenches upon the Constitution and laws of the United States, and this Constitution

official constitutional duty can be pumished under Federal law. What more appropriate legislation for enforcing a constitutional prohibition upon a State than to compel State officers to observe it?

Id. at app. 314. Clearly, Congress construed its enforcement powers under the fourteenth amendment very broadly.

181. See Lynch v. Household Fm. Corp., 405 U.S. 538, 545 (1972) ("The broad concept of civil rights embodied in the 1866 [Civil Rights] Act and in the Fourteenth Amendment is unmistakably evident in the legislative history of $\S 1$ of the Civil Rights Act of 1871.").

182. See Adickes v. S.H. Kress \& Co., 398 U.S. 144, 167-68 (1970); see also Parratt v. Taylor, 45I U.S. 527, 534-35 (1981) (negligent deprivation of constitutional rights is actionable under section 1983).

183. Monell v. New York City Dep't of Social Servs., 436 U.S. 658, 684-85 (1978).

184. Cong. Globe, 42d Cong., Ist Sess. app. 68 (1871). Representative Shellabarger continued: "Chief Justice Jay and also Story say: 'Where a power is remedial in its nature there is mucl reason to contend that it ought to be construed hberally, and it is generally adopted in the mterpretation of laws.' I STORY ON CONSTITUTION, sec. 429." Id. Representative Perry suggested that in passing the Civil Rights Act, Congress intended to use the full ineasure of its constitutional enforcement powers: "Now, by our action on this bill we have asserted as fully as we can assert the mischief intended to be remcdied. We have asserted as clearly as we can assert our belief that it is the duty of Congress to redress that mischief. We also have asserted as fully as we can assert the constitutional right of Congress to legislate." Id. at 800 ; see Maine v. Thiboutot, 448 U.S. 1, 45 (1980); Monell v. Department of Social Servs., 436 U.S. 658, 700-01 (1978). 
authorizes us to bring him before the courts to answer therefor. That covers, sir, all there is $\mathrm{m}$ the first and second sections of this bill. . . . I submit . . . that there is no tribunal so fitted, where equal and exact justice would be meted out im temper, in moderation, in severity if need be. ${ }^{185}$

Senator Frelinghuysen made clear that section 1 remedies should be used to redress denials of federal rights by state courts:

As to civil remedies, for a violation of [constitutional guaranties], we know that when the courts of a State violate the provisions of the Constitution or law of the United States there is now relief afforded by a review in the Federal courts. And simce the fourteenth amendment forbids any State from making or enforcing any law abridging these privileges and immumities ... the injured party should have an original action in our federal courts, so that by injunction or by the recovery of damages he could have relief against the party who under color of law is guilty of infringing his rights. As to the civil remedy no one, I think, can object. ${ }^{186}$

Opponents of the Civil Rights Act understood that its proponents mtended the federal courts to utilize section 1 remedies to reform the administration of justice im the South. Representative Holman complamed that "the jursidiction of the Federal courts, hitherto confined to questions of national concern, is to mvade the province of the State courts with new laws and systems of administration."187 Senator Thurman, another opponent, expressed sintilar concerns:

185. Cong. Globe, 42d Cong., 1st Sess. 476 (1871). Many other legislators explicitly intended the federal courts to act aggressively to protect federal rights. See, e.g., id. at 459 (Rcp. Coburn) (When there is a denial of equal protection by state officials, the "courts of justice of the nation stand with open doors, ready to receive and hear with impartial attention the complaints of those who are denied redress elsewhere."); see also id. at app. 79 (Rep. Perry), 376 (Rep. Lowe), 389 (Rep. Elliott), 448-49 (Rep. Butler), 691 (Sen. Edmunds), 653 (Sen. Osborn). The Supreme Court has recognized that "in passing $\S 1$, Congress assigned to the federal courts a paramount role in protecting constitutional rights." Patsy v. Board of Regents, 457 U.S. 496, 503 (1982).

186. CONG. GlobE, 42d Cong., 1st Sess. 501 (1871). Section 1 was modeled on section 2 of the Civil Rights Act of 1866, see supra text accompanying note 80, and was intended to provide a civil counterpart to the criminal sanctions in the earlier law. See Cong. Globe, 42d Cong., 1st Sess. 568-69 (reinarks of Sen. Edınunds), app. 68 (Rep. Shellabarger), 461 (Rep. Coburn) (1871); see also Chapman v. Houston Welfare Rights Org., 441 U.S. 600, 617 n.34 (1979). During the debates on the $1866 \mathrm{Act}$, opponents of section 2 complained that state judges could be inprisoned for violations of its provisions, and proponents explicitly acknowledged that this was their intent. See supra notes $92-94$ and accompanying text. Providing milder civil remedies against state judicial officers thus was relatively uncontroversial.

187. Cong. Globe, 42d Cong., Ist Sess. app. 258 (1871). Representative Eldridge, who also opposed the bill, interrupted Representative Holman's speech to ask:

Has any gentlenaan in favor of this bill given to this House . . . any idea of a limit beyond which the Federal Governnent may not go to the exclusion of the heretofore conceded jurisdietion of the States in the redress of the violation of the rights of person and property? I must confess I have not been able to understand them.

Id. at app. 260. Representative Holman replied:

The question of ny friend from Wisconsin is a very pertinent one. The record of the debate will answer the question. ... It is manifest the gentlenen recognize no such limit . . . . If Congress possesses the power to legislate at all by virtue of the limitations 
[The] whole effect [of section 1] is to give to the Federal Judiciary that which does not now belong to it - a jurisdiction that may be constitutionally conferred upon it, I grant, but that has never yet been conferred upon it. It authorizes any person who is deprived of any right, privilege, or immunity secured to him by the Constitution of the United States, to bring an action against the wrongdoer in the Federal courts, and that without any limitation whatsoever as to the anrount in controversy. . . . In the next place, I object to it because it is really, whatever else nray be said about it, a disparagement of the State courts. This bill embraces the whole Umited States; and to say that every man who may be imjured, however slightly, in his rights, privileges, or immunities as a citizen of the United States can go to the Federal courts for redress is to say, in effect, that the judiciary of the States is not worthy of being trusted. . . . [T]here is no limitation whatsoever upon the terms that are employed, and they are as comprehensive as can be used. ${ }^{188}$

Proponents of the Act also made clear that section 1 did not extend only to racial discrimination. Whites had been subjected to Klan violence, ${ }^{189}$ and southern state courts had routinely denied Union sympathizers due process and equal protection. ${ }^{190}$ As Representative Shellabarger stated, section 1 "not only provides a civil reinedy for persons whose former condition may have been that of slaves, but also to all people where, under color of State law, they or any of them may be deprived of rights to which they are entitled under the Constitution."191

Finally, the debates on the Civil Rights Act of 1871 reveal that Congress did not imtend the federal courts to withhold section 1 remedies if complainants could seek relief im the state courts. The issue was much discussed. Numerous opponents of the Act complained that section 1 remedies would improperly imterfere witl state court proceedings. ${ }^{192}$ They repeatedly asserted that the state courts were in most

imposed on States by the first section of the fourteenth amendment, it seems impossible to define any limit on the jurisdiction of . . . the Federal courts with respect to the measure of legislation affecting the great and varied subjects of domestic government. Id.

188. Id. at app. 216-17; see also id. at 352 (Rep. Beck), app. 88 (Rep. Storm), app. 50 (Rep. Kerr), 365-66 (Rep. Arthur), 373 (Rep. Archer), 385 (Rep. Lewis), 396 (Sen. Rice), app. 91 (Rep. Duke), app. 112 (Rep. Moore), app. 117-18 (Sen. Blair), app. 148 (Rep. Lamison), app. 179 (Rep. Voorhees), app. 304 (Rep. Slater).

189. See, e.g., id. at 156-57 (Sen. Slierman), 391 (Rep. Elliott), 412 (Rep. Roberts), 237 (Sen. Morton), app. $270-71$ (Rep. Havens), 456 (Rep. Coburn), 505-06 (Sen. Pool), 654 (Sen. Osborn).

190. See, e.g., id. at app. 251 (reinarks of Sen. Morton), app. 300 (Sen. Stevenson), 505 (Sen. Pratt), app. 185 (Rep. Platt).

191. Id. at app. 68; see id. at 696 (remarks of Sen. Edmunds); see also Monell v. Department of Social Servs., 436 U.S. 658, 683 (1978); Monroe v. Pape, 365 U.S. 167, 178 (1961).

192. See supra notes $187-88$ and accompanying text. 
cases enforcing the laws fully and equally, 193 and urged that enforcement of fourteenth amendment rights be left to these local tribunals. ${ }^{194}$ In response, numerous supporters of the Civil Rights Act contended that the federal courts must act because the state courts were either unable or unwilling to vindicate federal constitutional rights. As Senator Morton stated:

But it is said . . . the matter should be left with the States. The answer to that is, that . . . the States do not protect the rights of the people; the State courts are powerless to redress these wrongs. The great fact remains that large classes of people . . . are without legal remedies in the courts of the States. 195

Representative Coburn explained why the federal courts provided a superior forum:

The Umited States courts are further above mere local influence than the county courts; their judges can act with more independence, cannot be put under terror, as local judges can; their sympathies are not so nearly identified with those of the vicinage; the jurors are taken from the State, and not the neighborhood; they will be able to rise above prejudices or bad passions or terror more easily. . . . We beheve that we can trust our United States courts, and we propose to do so. ${ }^{196}$

Moreover, the legislative history of the Civil Rights Act does not indicate that the pendency of state proceedings should preclude a federal suit under section 1. Given Congress's persistent distrust of state courts, this is hardly surprising. The record of the previous eight years demonstrates that the Reconstruction Congresses repeatedly authorized interference with pending state proceedings, and often on a massive

193. See, e.g., Cong. Globe, 42d Cong., 1st Sess. 346-47 (remarks of Sen. Davis), 378-79 (Rep. Shoker), app. 160 (Rep. Golladay), app. 179 (Rep. Voorhees), 574 (Sen. Stockton) (1871).

194. See, e.g., id. at 361 (remarks of Rep. Swann), 429 (Rep. McHenry), app. 117 (Sen. Blair), 466 (Sen. Stockton), 480 (Rep. Lench), 604 (Sen. Saulsbury).

195. Id. at app. 252; see also id. at 201 (Sen. Nye) ("Sir, I would try the courts. Ah! what a mockery they have become . . . and yet we are told . . . we should wait and let reason have time to assume her throne. Sir, I have waited and waited until my ears have been pained with these reports [of the inaladministration of justice], and things grow worse. . . I I appeal to Senators ... to come up manfully to the duty, adopt the most stringent law that the Constitution will permit."), 505 (Sen. Pratt) ("Plausibly and sophistically it is said that the laws of North Carolina do not discriminate; that the provisions in favor of rights and liberties are general; that the courts are open to all . . . [But the laws] fail in efficiency when a man of known Union sentiments, white or black, invokes their aid."), app. 262 (Rep. Dunnell) ("Some here have contended that our protection must come from the State in which we chance to reside. . . [W]e are told the Federal Government has nothing to do in behalf of the citizen unless, indeed, the state authorities call for aid. These narrow views are repugnant to me."); see also id. at 394 (remarks of Rep. Rainey), 346 (Sen. Sherinan), app. 271 (Rep. Havens), app. 311 (Rep. Maynard), app. 183 (Rep. Platt).

196. Id. at 460; see District of Columbia v. Carter, 409 U.S. 418, 428 (1973); Mitchum v. Foster, 407 U.S. 225, 241 n.31 (1972). 
scale, when necessary to enforce federal constitutional rights. ${ }^{197}$ Therefore, as Representative Elliott explained, section 1 authorized "the assertion of immediate jurisdiction through [the federal courts], without the appeal or agency of the State in which the citizen is domiciled"198 to protect fundamental rights. 199

The Senate passed the Civil Rights Act by a vote of 36-13 on April 19, 1871.200 On April 20, the Senate received a report that the House had approved the measure as well. ${ }^{201}$ President Grant signed it into law the same day. ${ }^{202}$

The passage of the Civil Rights Act of 1871 marked the culmination of Congress's intense concern with the ongoing problems of violence and maladministration of justice in the South. Between 1865 and 1871 , Congress responded to these problems by passing the fourteenth amendment and a succession of related statutes in order to achieve systemic reform of the administration of both criminal and civil justice in the South.

197. In a series of at least eight enactments in the eight years preceding passage of the Civil Rights Act, and most recently in the Enforcement Act of February 28, 1871, see supra note 164, Congress had authorized and broadened the rights of litigants to remove both criuninal and civiI proceedings to federal court when fundamental rights were not effectively safeguarded in the pending state proceeding. See supra notes 137, 154; supra notes 82-83, 102-16 and accompanying text.

198. Cong. Globe, 42d Cong., 1st Sess. 389 (1871); see also id. at 692 (remarks of Sen. Edmunds). Representative Storm, an opponent of the Act, summed up the effect of section 1 as follows:

[Section 1] does not even give the State courts a chance to try questions or to show whether they will try the questions that might come before them under the first section of the fourteenth ainendment fairly or not. It takes the whole question away from thein in the beginning.

Now these questions could all be tried, I take it, in the State courts, and by a writ of error, as provided by the 25th section of the [Judiciary] act of 1789 , could be brought before the Supreine Court for review. . . . But the first section of this bill does not allow that right. It takes the whole question away at once and forever.

Id. at app. 86. Representative Wilson, a proponent, strongly suggested that the courts should honor Congress's wishes in interpreting section 1 :

It is for Congress to look to the question whether or not the State affords that protection the Constitution reqnires, and if it does not, then to provide the proper remedies.

And nnder [section 5 of the fonrteenth amendment] Congress is not only the exclusive judge of the necessity for application of remedies, but is also the exclusive judge of what the remedies shall be.

Id. at $482-83$.

199. The Supreme Court succinctly summarized this aspect of the debates on section 1 in Monroe v. Pape, 365 U.S. 167, 180 (1961):

It is abundantly clear that one reason the legislation was passed was to afford a federal right in federal courts because, by reason of prejudice, passion, neglect, intolerance or otherwise, state laws might not be enforced and the claims of citizens to the enjoyment of rights, privileges, and immunities guaranteed by the Fourteenth Amendment might be denied by the state agencies.

200. Cong. Globe, 42d Cong., Ist Sess. 831 (1871).

201. Id. at 832 .

202. Id. at 838; see Civil Rights Act of 1871 , ch. $22, \S 1,17$ Stat. 13. The Act also is reprinted in CONG. Globe, 42d Cong., Ist Sess. app. 335-36 (1871). 
The legislators intended the federal courts to be the primary enforcers of the rights guaranteed by the constitutional amendment and the newly-enacted laws. ${ }^{203}$ Congress authorized far-reaching federal court intervention in the day-to-day workings of southern justice systeins, making available virtually every possible reinedy: removal, habeas corpus, damages, injunctions, and crimmal prosecutions. ${ }^{204}$ The legislators firmly and repeatedly rejected suggestions that the federal courts should stay their hand in favor of theoretically available but demonstrably ineffective state court remedies. ${ }^{205}$ Congress had concluded that state courts neglected or refused to administer the laws in a fair and inpartial inanner. ${ }^{206}$ To the Reconstruction Congresses, abstention was anathema. ${ }^{207}$

\section{Evaluating the Younger Doctrine in Light of the LEGISLATIVE History OF RECONSTRUCTION}

The Civil War and Reconstruction wrought fundamental changes in the structure of the federal system. ${ }^{208}$ The federal government as-

203. See supra notes 137,164 ; supra notes $99,130,153,154$ and accompanying text.

204. The conclusion that Congress intended the federal courts to act vigorously to enforce the fourteenth amendment and the statutes of Reconstruction is strengthened by the prevailing assumption of the era that courts had a duty to provide remedies for violation of constitutional and statutory rights. In the nineteenth century, the maxim, "Where there is a right, there is a remedy," prevailed. See M'Culloch v. Maryland, 17 U.S. (4 Wheat.) 316, 407-08 (1819); Marbury v. Madison, 5 U.S. (1 Cranch) 137, 163 (1803). Thus, if a statute was enacted for a person's benefit and the person was harmed by its violation, a court would provide a reinedy even though the statute did not provide one. See Texas \& Pac. Ry. v. Rigsby, 241 U.S. 33, 39-40 (1916); Hayes v. Michigan Cent. R.R., 111 U.S. 228, 240 (1884); Couch v. Steel, 3 El. \& Bl. 402, 118 Eng. Rep. 1193, 1196-97 (1854); 1 Comyns' Digest 443-45 (A. Hammond, 5th ed. London 1822) (1st ed. London 1776). See generally W. PROSSER, HANDBOOK OF THE LAW OF TORTS 190-204 (4th ed. 1971) (citimg numerous state court cases of the late 1800's implying private rights of action from statutes).

205. See supra note 137; supra notes $74,87-90,99,154,192$ and accompanying text.

206. See supra note 137; supra notes $72-3,91-4,151,163,171-77,195$ and accompanying text.

207. The Republican-controlled Forty-third Congress, which remamed in office until March, 1875 , passed the last two civil rights measures of this era. One sought to redress the states' failure to protect blacks against discrimination in pubhic accommodations, Act of Mar. 1, 1875, ch. 114, 18 Stat. 336, and the other extended the jurisdiction of the lower federal courts to all federal question cases, Act of Mar. 3, 1875, ch. 137, $\S \S 1-2,18$ Stat. 470 (codified at 28 U.S.C. $\S 1331$ (Supp. V 1981)). These Acts marked the end of congressional Reconstruction. See generally C. Woodward, Reunion and Reaction: The Compromise of 1877 and the END of ReConSTRUCTION (1951).

208. These changes were not immediately apparent because the Supreme Court progressively evisceratcd the constitutional amendments and enforcement legislation of Rcconstruction in the last decades of the nimeteenth century. See, e.g., Barney v. City of New York, 193 U.S. 430, 43739 (1904) (holding conduct by state officials in violation of their authority not to be state action within section 1 of the fourteenth amendinent); The Civil Rights Cases, 109 U.S. 3, 11-12 (1883) (reiterating that Congress's enforcement powers under section 5 of the fourteenth amendment were linited to state action); United States v. Harris, 106 U.S. 629, 641-44 (1882) (holding uncon- 
sumed the role of guarantor of individuals' federal rights against state power, ${ }^{209}$ and the federal courts became the primary enforcers of federal rights. ${ }^{210}$ In recent decades the federal courts have inade broad use of their equitable powers under the fourteenth amendment and the Reconstruction statutes to effect systemic change in the adininistration of state and local government by desegregating schools, ${ }^{211}$ reapportioning legislatures, ${ }^{212}$ and improving conditions of confinement for institutionalized persons. ${ }^{213}$ Courts have generally refused, however, to use those powers to reform state criminal and civil justice systeins. ${ }^{214}$ The chief impediment has been the Younger $v$. Harris nonintervention doctrine. ${ }^{215}$ As noted earlier, Supreme Court decisions applying and ex-

stitutional part of section 2 of the Civil Rights Act of 1871 because it reached private conduct); United States v. Cruikshank, 92 U.S. 542, 559 (1876) (reducing rights protected by section 6 of the Enforcement Act of May 31, 1870); Slaughter-House Cases, 83 U.S. (16 Wall.) 36, 74-81 (1873) (excluding inost civil rights froin scope of fourteenth amendinent's privileges and immunities clause). See generally Developments in the Law-Section 1983 and Federalism, supra note 156, at 1156-61.

During the twentieth century, the Supreme Court has interpreted the Reconstruction measures to broaden the interests the federal government is allowed to protect and to increase the range of conduct proscribed by the fourteenth amendinent. See, e.g., Patsy v. Board of Regents, 457 U.S. 496, 503 (1982) (rejecting requirement that plaintifis in section 1983 actions exhaust state administrative remedies); Jones v. Alfred H. Mayer Co., 392 U.S. 409, $421-22$ (1968) (extending 42 U.S.C. § 1982 to private racial discrimination in housing); United States v. Classic, 313 U.S. 299, 325-29 (1941) (defining "under color of" law requirement of section 20 of the Criminal Code, currently codified at 18 U.S.C. $\$ 242$ (1976), to include action by state officers in violation of state law); Monroe v. Pape, 365 U.S. 167, 184-85 (1961) (defining "under color of" law for section 1983 action in the same manner as for section 242); Nixon v. Herndon, 273 U.S. 536, 539-40 (1927) (approving section 1983 damage action against election judges who complied with a state statute prohibiting blacks froin voting); Home Tel. \& Tel. Co. v. City of Los Angeles, 227 U.S. 278, 28386 (1913) (rejecting argument that official action was not state action under fourteenth amendinent until state courts determined the action to be authorized by state law); Ex parte Young, 209 U.S. $123,157-60$ (1908) (holding that suit against a state official alleging a fourteenth amendment violation is not barred by the eleventh amendment). See generally Developments in Law-Section 1983 and Federalism, supra note 156, at 1167-72.

209. See Mitchum v. Foster, 407 U.S. 225, 238-39 (1972); see also Patsy v. Board of Regents, 457 U.S. 496, 502 (1982).

210. See F. Frankfurter \& J. Landis, The Business of the Supreme Court 65 (1927); see also Zwickler v. Koota, 389 U.S. 241, 246-48 (1967); Monroe v. Pape, 365 U.S. 167, 172-80 (1961); Amsterdam, supra note 48, at 828.

211. See, e.g., Swann v. Charlotte-Mecklenburg Bd. of Educ., 402 U.S. 1, $15-18$ (1971); Griffin v. County School Bd., 377 U.S. 218, 230-34 (1964); Brown v. Board of Educ., 349 U.S. 294, 298301 (1955).

212. See, e.g., Reynolds v. Sims, 377 U.S. 533, 583-87 (1964); Wesberry v. Sanders, 376 U.S. 1, 7-18 (1964); Gray v. Sanders, 372 U.S. 368, 376-81 (1963); Baker v. Carr, 369 U.S. 186, 208-37 (1962).

213. See, e.g., Rhem v. Malcolm, 371 F. Supp. 594, 625-27 (S.D.N.Y.), affd and remanded, 507 F.2d 333 (2d Cir. 1974).

214. See, e.g., Rizzo v. Goode, 423 U.S. 362, 376-80 (1976); O'Shea v. Littleton, 414 U.S. 488, 677-79 (1974). But see, e.g., Gerstein v. Pugh, 420 U.S. 103, 116-18 (1975).

215. 401 U.S. 37 (1971); see supra notes 1-8 and accompanying text. 
tending that doctrine are largely devoid of discussion of the legislative history of Reconstruction. ${ }^{216}$ Examining Younger and its progeny in view of that legislative history sheds new light on these cases and demonstrates that the federal courts have been wrong in refusing to use their equitable powers to reform state justice systems.

\section{A. Younger v. Harris.}

Younger is an appropriate place to begin exannination of the doctrine of equitable restraint; in Younger the Court laid the foundation for routine dismissal of most cases brought in federal court that implicate ongoing state judieial proceedings. Plaintiff Harris was indicted under California's Criminal Syndicalisin Act for "distributing leaflets advocating change in industrial ownership through political action."217 Although the Califonia Act was vulnerable to serious constitutional challenge, ${ }^{218}$ District Attorney Younger pursued the case. ${ }^{219}$ Harris moved unsuccessfully in the Califorina trial court to have the ease dismissed on constitutional grounds. When his petitions to the state appellate courts for writs of prohibition were also demied, Harris turned to a federal court for an injunction against further proseeution.220 A three-judge federal district court held the statute unconstitutional and granted the injunction. ${ }^{221}$ The Supreme Court reversed, eitmg "the national policy forbidding federal courts to stay or enjoin pending state court proceedings except under speeial circumstances."222

Justice Black wrote the opinion of the Court ${ }^{223}$ in Younger. He developed an elaborate rationale for why federal courts should decline to hear certain cases that otherwise ineet all the requisites of federal jurisdiction. Justice Black cited the "ideals and dreains of 'Our Federahism," "which for him inandated "a proper respeet for state functions" and required that state institutions be allowed "to perfonn their separate functions in their separate ways."224 He found support for "Our

216. See supra note 10 and accompanying text.

217. Younger v. Harris, 401 U.S. 37, 60 (1971) (Douglas, J., dissenting).

218. In 1969, one year after the lower court decision in Younger, the Supreme Court held a similar Ohio statute unconstitutional. See Brandenburg v. Ohio, 395 U.S. 444, 447-49 (1969). Brandenburg gave short shrift to Whitney v. California, 274 U.S. 357 (1927), which had upheld the California law, stating "Whitney has been thoroughly discredited by later decisions." 395 U.S. at 447.

219. Harris v. Younger, 281 F. Supp. 507, 509-10 (C.D. Cal. 1968), rev'd, 401 U.S. 37 (1971),

220. Harris v. Younger, 281 F. Supp. 507, 510 (C.D. Cal. 1968), rev'd, 401 U.S. 37 (1971).

221. Harris v. Younger, 281 F. Supp. 507, 517 (C.D. Cal. 1968), rev'd, 401 U.S. 37 (1971).

222. Younger, 401 U.S. at 41.

223. Only Justices Burger and Blackmun joined fully in Justice Black's opinion of the Court.

224. Younger, 401 U.S. at 44. 
Federalism" in the debates surrounding the drafting of the Constitution. ${ }^{225}$

When Justice Black's opinion is juxtaposed with the legislative history of Reconstruction canvassed above, his vision of American federalism appears fundamentally flawed, at least as to the allocation of responsibility for vindication of federal constitutional riglits. All of Justice Black's references to history concern the period when the Constitution was originally framed. He "disregard[ed] such intervening events as the Civil War, the fourteenth amendment, the Civil Riglits Act [and] the federal jurisdictional grants of the Reconstruction era."226 As the Court held one year after Younger in Mitchum v. Foster, 227 "[t]his legislative history makes evident that Congress clearly conceived that it was altering the relationship between the States and the Nation with respect to the protection of federally created rights," and was establishing "the federal Government as a guarantor of [these] rights against state power."'228

Justice Black exaggerated the deference owed by federal courts to state courts when plaintiffs invoke section 1983. Congress clearly intended section 1983 remedies to be used to redress denials of federal rights by state courts, 229 and did not intend a federal court to decline to exercise jurisdiction just because a complainant could raise his clainus in state court. ${ }^{230}$ Instead, as Representative Elliott explaimed, section 1 of the Civil Riglits Act of 1871 authorized "the assertion of immediate jurisdiction through [the federal courts] without the appeal or agency of the state in which the citizen is domiciled."231

\section{Id. at 44-45.}

226. Gibbons, Our Federalism, 12 SuFfolk U.L. Rev. 1087, 1104 (1978); see also Fiss, Dombrowski, 86 YALE L.J. 1 103, 1118 (1977); Soifer, supra note 20, at 651 n.5; Soifer \& Macgill, The Younger Doctrine: Reconstructing Reconstruction, 55 Tex. L. REv. 1141, 1170 (1977); cf. Screws v. United States, 325 U.S. 91, 116 (1945) (Rutledge, J., concurring) ("Vague ideas of dual federalism ... do not nullify what four years of civil strife secured and eighty years have verified. For it was abuse of basic civil and political rights, by states and their officials, that the [fourteenth] Amendment and the enforcing legislation were adopted to uproot.").

227. 407 U.S. 225 (1972).

228. Id. at 242, 239. In Younger, only Justice Douglas, who dissented, referred to the legislative history of Reconstruction. He observed that under the fourteenth amendment, section 1983, and 28 U.S.C. $\S 1343$, "the balance of the pressures of localism and nationalism . . . were fundamentally altered," 401 U.S. at 61 , and that section 1983 was an expression of Congress's desire to " "interpos[e] the federal government between the states and their inhabitants," "id. at 63 (quoting opinion of Judge Will in the companion case of Landry v. Daley, 288 F. Supp. 200, 223 (N.D. Ill. 1968), rev'd sub nom. Boyle v. Landry, 401 U.S. 77 (1971)).

229. See supra note 186 and accompanying text.

230. See supra notes $192-99$ and accompanying text.

231. CoNG. Globe, 42 d Cong., Ist Sess. 389 (1871) (emphasis added). Moreover, Rep. Storm, an opponent of the Act, explicitly recognized that section 1 did not require litigants to pursue the state appellate route imphicitly prescribed for Harris by the Younger Court: "Now these [fourteenth amendment] questions could all be tried, I take it, in the State courts, and by a writ of error, 
The Younger Court could have argued that federal courts should divest themselves of jurisdiction im these cases, im spite of the legislative history of section 1983, because times have changed since 1871 and dramatic intervention to prevent state court abuses is no longer warranted. Yet the Younger Court eschewed such an explanation, perhaps because the civil rights problems of the 1950's and 1960's demonstrated that times had not changed. It is true that the Reconstruction Congresses were not thinking about criminal syndicahsm statutes or the first amendment rights of California sociahsts when they passed the fourteenth amendment and section 1983. Nevertheless, the actions of the state officials in Younger are analogous to the abuses which prompted the Reconstruction enactments.

Ultimately, the propriety of the Court's decision in Younger depends on how one thinks constitutional provisions and remedial statutes should be interpreted decades or centuries after their adoption and enactment. Noninterpretivists presumably would have little trouble applymg the fourteenth amendment and section 1983 to a case like Younger, which fits squarely within the broad language of those measures. ${ }^{232}$ But imterpretivists would insist that the work of state officials should "be invalidated only in accord with an inference whose starting point, whose underlying preimse, is fairly discoverable in the Constitution." They would not insist, however, that "the complete imference be found there-because the situation is not likely to have been foreseen." ${ }^{233}$ The fourteenth amendment and the remedial statutes enacted to enforce it were passed to overturn discriminatory state legislation and to prevent state court harassment of persons holding unpopular political views. ${ }^{234}$ The Reconstruction Congresses considered and rejected the possibility that federal courts should decline to exercise their jurisdiction over cases challenging actions in ongoing state criminal proceedings. ${ }^{235}$ Therefore, the imference that the federal court should have intervened to overturn California's law and enjom prosecution of Harris arguably has its "starting point," and its "underlying premise,"

as provided by the 25 th section of the [Judiciary] [A]ct of 1789, could be brought before the Supreme Court for review. . . . But the first section of this bill does not allow that right. It takes the whole question away at once and forever." Id. at app. 86.

232. See supra text accompanying note 13 .

233. J. ELY, supra note 13, at 2 . As Professor Joseph Grano states, "a narrow interpretivism must be rejected unless we are prepared to take the radical step at this late date of reducing the Constitution to nothing more than a code aimed at the framers' particularized grievances." Grano, Judicial Review and a Written Constitution in a Democratic Society, 28 WAYNE L. REv. 1, 63 (1981); see also Mishkin, Federal Courts as State Reformers, 35 WASH. \& LeE L. Rev. 949, 96162 (1978).

234. See supra note 186 and accompanying text.

235. See supra notes 70-76, 192-99 and accompanying text. 
in the Constitution and laws. Admittedly, however, the matter is not wholly free of doubt.

B. O'Shea v. Littleton.

Whether legislative intent supported federal court intervention in Younger is at least debatable. In O'Shea v. Littleton ${ }^{236}$ it is simply not debatable. The fourteenth amendment and section 1983 were passed specifically so that federal courts would act in cases like $O$ 'Shea. The lawsuit grew out of the racial troubles in Cairo, Illinois. Long-smoldering grievances of Cairo's black minority ${ }^{237}$ ignited in violence during the suminer of 1967 following the mysterious death of a black soldier in a city jail. ${ }^{238}$ The National Guard was called in to restore order. ${ }^{239}$ In the wake of the disturbances, soine 500 to 600 whites forned a vigilante group which became known as the "White Hats" because of the white plastic civil defense helmets they wore. ${ }^{240}$ Led by Peyton Berbling, state prosecuting attorney for Alexander County, ${ }^{241}$ the White Hats, armed with rifles, patrolled Cairo streets in radio-equipped cars. ${ }^{242}$ Nearly 450 of the vigilantes were deputized, ${ }^{243}$ making "it legal for them to carry a weapon."244 During 1967 and 1968, blacks charged that the White Hats "roained freely, armed and agressive [sic], intimidating the black cominunity."245

236. 414 U.S. 488 (1974).

237. These grievances included racial discrimination in housing, employment, and education. Fiss, supra note 226, at 1150. See generally P. Good, U.S. Commission ON Civil Rights, CaIRo, ILliNoIS: RACISM AT FLOODTIDE 37-48 (education), 56-64 (housing), $65-74$ (employinent) (1973); Seng, The Cairo Experience: Civil Rights Litigation in a Racial Powder Keg, 61 OR. L. Rev. 285, 286-90 (1982).

238. See P. Good, supra note 237, at 15-16; Janson, Guardsmen Patrol in Cairo, Ill. After Three Nights of Violence, N.Y. Times, July 20, 1967, at 27, col. 1. Police clained the soldier had hung himself with his tee-shirt, but inany residents were suspicious and charged police brutality. No autopsy was performed, so the truth was never discovered. See id. at 15.

239. See Janson, supra note 238, at 27, col. 1; Janson, Negroes Demand Action by Cairo, Ill., N.Y. Times, July 21, 1967, at 35, col. 6; see also P. GooD, supra note 237, at 16.

240. See Lukas, Bad Day at Cairo, Ill., N.Y. Times, Feb. 21, 1971, § 6 (Magazine) at 22, 83; see also P. GooD, supra note 237, at 16-17; Janson, Cairo, Ill., Divided by Racial Conflict; City Fears Future, N.Y. Times, June 23, 1969, at 1, col. 1; King, Cairo, Ill., Is Quiet as Guard Patrols, N.Y. Times, May 1, 1969, at 30, col. 4. Cairo's vigilante tradition is reviewed in Lukas, supra, at 64.

241. P. Good, supra note 237, at 16; Lukas, supra note 240, at 83; Janson, supra note 240, at 29 , col. 1 .

242. Lukas, supra note 240 , at 83 ; Janson, supra note 240 , at 29 , col. 1 .

243. P. Good, supra note 237, at 18; Lukas, supra note 240, at 83.

244. Janson, supra note 240, at 29, col. 1 (quoting Harry L. Bolen, president of the Cairo Chamber of Commerce).

245. P. GooD, supra note 237 , at 18 . Cairo's criminal justice system generally failed to protect blacks from the White Hats during this period. Given the official complicity in the group's formation and in the naming of deputies, this is hardly surprising. One incident is particularly reminiscent of the sorts of imcidents that inflamed Congress in 1867. On July 30, 1968, Reverend Larry 
Blacks responded in the spring of 1969 by beginning an economic boycott of Cairo's white-owned businesses. ${ }^{246}$ Picketing led to renewed violence and arrests during the summer. ${ }^{247}$ Charges were made that criminal justice officials applied the laws unequally. ${ }^{248}$ The boycott and the violence continued for the next three years. Journalist Paul Good summed up the events of this period as follows:

Intermittently over the next three years, Cairo would hear gunfire, live with fear. Two of its mayors would resign, four police chiefs would either resign or be fired . . . , and hundreds of citizens-the vast majority black - would be jailed as an outgrowth of demonstrations. During the next 11 months alone there would be at least 80 separate shooting imcidents, most centered around the all-black Pyramid Courts where some residents took to sleeping in bathtubs at night to escape fusillades that pierced walls and windows. There was not a simgle arrest made by the Police Department in these shootimgs. ${ }^{249}$

The plaimtiffs in $O^{\prime} S h e a^{250}$ sought federal court assistance in remedying the problems with the administration of justice in Cairo. Thcy commenced a class action seeking damages and injunctive relief agamst the state's attorney for Alexander County (Berblimg), his investigator, the Cairo police commissioner, and two judges of the Alexander County Circuit Court.251 The plaintiffs alleged that the defendants were intentionally engaged in a systematic and continumg program of racial discrimination in the administration of crimmal justice, and that

Potts, a White Hat member, "used a baseball bat to beat to death a 73-year-old black man he said was attempting to rape his wife. A coroner's jury absolved him of any guilt." P. GooD, supra note 237 , at 17 .

Vigilante violence in Cairo was not aimed solely at blacks. White sympathizers were also victimized. Id. at 21; King, supra note 240, at 30, col. 3; King, In Cairo, Ill, Racial Tensions Remain High After Week of Shooting and Arson, N.Y. Times, Oct. 27, 1970, at 27, col. 1.

246. Lukas, supra note 240 , at 83.

247. See N.Y. Times, April 1, 1969, at 29, col. 8; id., April 28, 1969, at 7, col. 1; id., April 30, 1969, at 23, col. 1; King, supra note 240 , at 30 , col. 3. In June, 1969, the White Hats disbanded under pressure from state officials. Shortly thereafter, however, the organization was replaced by the United Citizens for Community Action, a group with "largely the same membership and apparently much the same purposes." Lukas, supra note 240, at 83; see also P. GooD, supra note 237, at 18 .

248. Reverend Jesse Jackson of the Southern Christian Leadership Conference charged: "There is not only a breakdown of justice in Cairo, there is a breakdown of law and order." Janson, New Chief in Cairo, Ill., N.Y. Times, June 17, 1969, at 28, col. 1.

249. P. Good, supra note 237, at 18. The Unitcd States Commission on Civil Rights held hearings in Cairo in March, 1972. Witnesses testified that Cairo law enforcement officials were untrained amateurs who failed to protect black citizens and enforced the laws unequally. The police also were charged with brutality and with acting in complicity with white vigilantes. $I d$. at 26-32.

250. 414 U.S. 488 (1974). The plaintiffs were nineteen citizens of Cairo; all but two were black. $\int d$. at 491 .

251. Id. at 490. 
this program violated their first, sixth, eighth, thirteenth, and fourteenth amendment rights as well as their rights under 42 U.S.C. $\S \S 1981,1982,1983$ and $1985 .{ }^{252}$ Berbling was charged with prosecuting blacks more harshly than whites, ${ }^{253}$ and the judges were charged with similar abuses in setting bail and in sentencing. ${ }^{254}$

The district court dismissed the complaint for lack of jurisdiction and on the grounds that the judges were immune from suit for acts done in their judicial capacity. The court of appeals reversed, remanded, and ordered the district judge to grant appropriate injunctive relief if the plaintiffs proved their case. ${ }^{255}$ The Supreme Court reversed the court of appeals, invoking the doctrine of Younger v. Harris. ${ }^{256}$ The $O$ 'Shea Court wanted to avoid "abrasive and unmanageable intercession"257 into the day-to-day conduct of local criminal proceedings. By seeking "an injunction aimed at controlling or preventing the occurrence of specific events that might take place in the course of future

252. Id. at 490-91. Jurisdiction was based on 28 U.S.C. $\$ \S 1331,1343$ (Supp. V 1981).

253. Specifically, Berbling was charged with refusing to initiate criminal proceedings against whites on the complaints of blacks. In those few cases where he did permit complaints, he submitted the cases to a grand jury rather than proceeding by prosecutor's information. Before the grand jury, he presented evidence in a manner designed to secure dismissal of the charges. Berbling also was charged with lax prosecution of cases against whites, and with purposely losing such cases. He also allegedly recommended relatively higher bonds for blacks than for whites, and filed higher charges against blacks than whites for similar misconduct. Berbling's investigator was charged with refusing to receive evidence from blacks against whites, and with conspiring with Berbling to this end. See Littleton v. Berbling, 468 F.2d 389, 392-93 (7th Cir. 1972), rev'd sub nom. O'Shea v. Littleton, 414 U.S. 488 (1974); see also Spomer v. Littleton, 414 U.S. 514, 516-18 (1974) (the companion case to $O$ 'Shea).

254. The defendant judges were alleged to have set bonds according to an unofficial schedule rather than tailoring bail to the facts of each case. They were also charged with imposing longer sentences on blacks than on whites for the same offenses, and with requiring blacks to pay for jury trials. Littleton v. Berbling, 468 F.2d 389, 393-94 (7th Cir. 1972), rev'd sub nom. O'Shea v. Littleton, 414 U.S. 488 (1974).

255. Berbling, 468 F.2d at 414-15. The court of appeals also held that the judges and prosecutor Berbling were immune from damage claims for acts done in their judicial or prosecutorial capacity. Id. at 395-410. The court refused to extend immunity, however, to acts by Berbling or his investigator that resembled pohce rather than prosecutorial functions. Id at 410 .

256. O'Shea, 414 U.S. 488, 499-504 (1974). The Court also held that the complaimt failed to present a case or controversy. The majority beheved it unlikely that the named plaintiffs would in the future be subjected to the kinds of injury described in the complaint. See id. at 495-99. This holding evoked a vigorous dissent from Justices Douglas, Brennan, and Marshall. The dissent pointed out that the named plamtiffs clanned that they had personally snffered from the defendants' misconduct and that the defendants continued to engage in discriminatory practices. 414 U.S. at 507-08 (Douglas, J., dissenting). These allegations convimced the dissenters that it was hikely that the named plaintiffs as well as members of the class would be arrested in the future and subjected to discrimination. Id. at 509. Justice Douglas concluded: "This is a more pervasive scheine for suppression of blacks and their civil rights than I have ever seen. It may not survive a trial. But if this case does not present a 'case or controversy' involving the named plaintifis, then that concept has been so watered down as to be no longer recognizable." Id.

257. 414 U.S. at 504. 
state criminal trials," the plaintiffs seemed to "contemplate interruption of state proceedings to adjudicate assertions of noncompliance" in an "ongoing federal audit of state criminal proceedings." 258 Thus, granting the relief requested "would indirectly accomplish the kind of interference that Younger v. Harris ... and related cases sought to prevent."259 The Court suggested that the plaintiffs instead should pursue such state remedies as a motion for a cliange of venue or for substitution of a judge, review by direct appeal or by postconviction collateral remedies, or institution of disciplinary proceedings. ${ }^{260}$

The majority in O'Shea never mentioned the legislative history of Reconstruction, ${ }^{261}$ despite the plaintiff's reliance on the constitutional amendments and legislation of that period. The legislative history demonstrates that a dismissal pursuant to Younger was wholly inappropriate in $O^{\prime}$ 'Shea ${ }^{262}$ The criminal justice abuses in Cairo bear an uncanny resenblance to the abuses in the post-Civil War South. ${ }^{263}$ Exactly the same kinds of complaints against exactly the saine criminal justice officials are involved in each instance. During Reconstruction, southern police and prosecutors were charged with failing to protect blacks against white violence, failing to investigate crimes by whites against blacks, and failing to arrest whites on the complaint of blacks. ${ }^{264}$ Nearly identical allegations were made in O'Shea. ${ }^{265} \mathrm{Re}-$ construction legislators, like the plaintiffs in $O^{\prime} S h e a$, complained of grand jurors' failure to indict whites for crimes against blacks. ${ }^{266}$ From

258. Id. at 500 .

259. Id. The Supreme Court considered the claims against Berbling in a related action, Spomer v. Littleton, 414 U.S. 514 (1974). Because Berbling had been replaced as State's Attorney by the time the Supreme Court heard the case, the Court reinanded the claims against Berbling with directions to the Court of Appeals to investigate whether they were moot. Id. at 522. Owen Fiss has strongly criticized this result. See Fiss, supra note 226, at 1150-51.

260. O'Shea, 414 U.S. at 502 . The Court also suggested federal habeas corpus or federal crimmal prosecutions under 18 U.S.C. \& 242 (1976). Id. at 502-03.

261. Neither, for that inatter, did the concurring or dissenting justices.

262. Candor coinpels the author to admit that his views on $O$ 'Shea have been substantially altered by viewing it in hight of the legislative history. Cf. Ziegler, supra note 2, at 288-89 (arguing that the Younger doctrine was applied correctly in O'Shea v. Litlleton).

263. The resemblance between Cairo and the South of 100 years before was explicitly recognized by Cairo officials and residents. When Sheriff Roy Burke resigned his post, he complamed: "This community has a post-Civil War attitude with its fear, repression and economic problems." N.Y. Times, Sept. 21, 1970, at 18, col. 5. Another resident thought the white leadership was "still in the 19th Century." N.Y. Times, Oct. 27, 1970, at 27, col. 3. Reporter Anthony Lukas noted that Cairo is farther South than Richmond, Virginia, and "its racial attitudes are not very different from those of Selina, Ala. or Jackson, Miss." Lukas, supra note 240, at 82-83.

264. See supra note 145; supra note 173 and accompanying text.

265. See supra notes 251-54 and accompanying text; see also supra notes 248-49 and accompanyimg text.

266. See supra note 174 and accoinpanying text. 
1865 to 1871 , state judges were repeatedly accused of failing or refusing to execute the laws impartially, ${ }^{267}$ of discriminating in favor of southern whites against loyahists and blacks, ${ }^{268}$ and of abusing their bailsetting powers. ${ }^{269}$ Similar discriminatory activities were charged against the defendant judges in O'Shea ${ }^{270}$

Finally, during Reconstruction criminal justice officials were charged with failing to protect blacks and loyalists from vigilante organizations such as the Ku Klux Klan, with being Klan members theinselves, and with acting in comphicity with Klan inembers. ${ }^{271}$ The parallels between the Klan and Cairo's White Hats are remarkable. Not only did Cairo officials fail to protect blacks and white sympathizers against the White Hats, the officials deputized the vigilantes so that they could act in the name of the law. Indeed, the prosecuting attorney was the chief organizer of the group.

Congress enacted the fourteenth amendment and the numerous pieces of enforceinent legislation examined in Section II so that the federal government could correct the sort of systemic maladmmistration of justice evident in Cairo. Section 1 of the fourteenth amendment was passed primarily to enable Congress to enact legislation requiring states to administer justice fairly. ${ }^{272}$ Section 1 of the Civil Rights Act of 1871, which created a private right of action against state officials for violation of federal law and gave the federal courts jurisdiction over such claims, was enacted specifically to address the twm probleins of Klan violence and maladministration of justice in the South. ${ }^{273}$ In short, these measures were specifically aimed at abuses like those that occurred in Cairo, Illinois.

The legislative history demonstrates that the Court erred in relegating the O'Shea plaintiffs to state remedies. Throughout the Reconstruction era, and particularly during the debates on the Civil Rights Act of 1871, Congress rejected the suggestion that those aggrieved by a state official's misconduct must pursue local remedies. 274 Congress did not suggest that the federal courts should stay their hand if the state courts arguably became more rehable at some future time. Instead, the

267. See supra note 145; supra notes $91,132,176-77$ and accompanying text.

268. See supra note 177 and accompanying text.

269. See supra note 145; supra note 176 and accompanying text.

270. See supra note 254 and accompanying text.

271. See supra note 145 ; supra note 171 and accompanying text.

272. See supra notes $128-33$ and accompanying text.

273. See supra notes $165,170-80$ and accompanying text.

274. See supra note 137; supra notes $71-74,87-91,99,154,192-99$ and accompanying text. 
legislators created a federal remedy supplementary to the state remedy. 275

There are good reasons for making federal relief supplementary to potential state remedies. It is virtually impossible for a federal judge to know whether theoretically available state remedies will in fact be adequate to vindicate federal rights. The federal judge must guess whether the state process is so imfluenced by local politics and prejudices or so hindered by practical deficiencies that protection of federal rights is uncertam. Judges faced with this dilemma will be tempted to do what the Court did in O'Shea-presume the adequacy of all alternative remedies without evaluating their true effectiveness. As Owen Fiss has noted, the "adequacy of [the] alternative remedies [im O'Shea] was evidently to be presuuned from the very fact that Justice White was able to think of them."276 Once a federal court dismisses a case because of the Younger doctrine, litigants do not lave the opportunity to return to federal court to demonstrate that the judge guessed wrong and that state remedies were unavailing. The presumption of the adequacy of state remedies is irrebuttable. ${ }^{277}$

275. Monroe v. Pape, 365 U.S. 167, 183 (1961); see also Patsy v. Board of Regents, 457 U.S. 496, 506-07 (1982).

276. Fiss, supra note 226 , at 1154 . State remedies are rarely adequate for achieving systemic relief. See Neuborne, The Myth of Parity, 90 HARv. L. REv. 1105, 1115-28 (1977); Zeigler, stupra note 2 , at $305-06$.

277. In $O$ 'Shea, the Court exaggerated the difficulties that the federal district court faced in fashioning equitable rehef. First, prior to trial the Court should not have assumed that broadbased rehef was necessary. Assuming that the plamtiffs showed the appropriateness of some relief, there were many steps that could have been taken short of placing the Cairo criminal justice system in receivership. As the court of appeals suggested, an "initial decree might set out the general tone of rights to be protected and require only periodic reports of various types of aggregate data on actions on bail and sentencing and dispositions of complaints." Littleton v. Berbling, 468 F.2d 389, 414-15 (7th Cir. 1972), rev'd sub nom. O'Shea v. Littleton, 414 U.S. 488 (1974).

Even assuming that the intransigence and bigotry of the defendants ultimately necessitated "continuous or piecemeal interruptions of state proceedings . . . in an ongoing federal audit," O'Shea v. Littleton, 414 U.S. 488, 500 (1974), the court would still be acting withim its authority. Cairo only has 6000 residents, Lukas, supra note 240 , at 82 , and the plaintiffs named only five officials as defendants. Momitoring their praetices closely would not have been unworkable. Moreover, the Reconstruction Congresses clearly intended that the federal courts should do all that was necessary to remedy serious violations of federal rights in state criminal and civil justice systems. See supra notes 70-73, 84-93, 181-88 and accompanying text. Legislators who authorized the removal of thousands of cases froin state to federal court lock, stock, and barrel, see supra notes 136-37 and notes 83-86, 101-18 and accompanying text, and who sought systeinic reform of the justice systems of eleven states would hardly have balked at a federal judge looking over the shoulders of five officials in Cairo, Illinois. At the very least, it is plain that the Reconstruction legislators would have disapproved dismissal of the case at the outset. Indeed, in light of the legislative history of Reconstruction, it is difficult to inagine a less appropriate case for abstention than O'Shea $v$. Litlleton.

Happily, persistent efforts by the Lawyer's Committee for Civil Rights Under Law and its successor organization, The Land of Limcoln Legal Assistance Foundation, have led to some gams 


\section{Rizzo v. Goode.}

O'Shea was the first Supreme Court decision extending Younger to bar the use of federal injunctions for systemic reform of state criminal justice practices. The Supreme Court reaffirmed this prohibition two years later in Rizzo v. Goode. ${ }^{278}$ In light of the legislative history discussed in Section II, Rizzo seems almost as inappropriate a case for abstention as $O$ 'Shea.

The Rizzo litigation grew out of allegations of pervasive, raciallymotivated police brutality im Philadelphia, Pemisylvania. ${ }^{279}$ A number of individuals and organizations filed two section 1983 class actions in federal district court in 1970 against the Mayor, the City Managing Director, the Police Commissioner, a Deputy Police Commissioner, and a Police Captain, ${ }^{280}$ alleging a widespread pattern of police brutality toward blacks. The plamtiffs clamied that these officials knew of the police misconduct and had tacitly condoned it by failing to take effective steps to reduce the incidence of brutality. Plaintiffs in one action called for "reinoval or other appropriate disciplimary action in the cases of certain named policemen; and establishment of appropriate nuachmery to deal with civilian counplaints against police."281 Plaintiffs in the other action asked the court to apponit a receiver to supervise the police department and prevent further violations. ${ }^{282}$

The district court heard approximately 250 witnesses in learings

for Cairo's black citizens in recent years in the areas of employment, housing, and political representation. See Seng, supra note 237, at 300-12.

278. 423 U.S. 362 (1976). For a perceptive commentary on Rizzo, see Weinberg, The New Judicial Federalism, 29 Stan. L. Rev. $1191,1215-27$ (1977).

279. Although police brutality lias been a concern in many large American cities, see generally President's Commission on Law Enforcement and Administration of Justice, Task Force Report: The Police 178-207 (1967), in the late 1960's and early 1970's Philadelphia had special problems. These were attributable, in part, to the attitudes and actions of Police Commissioner (and later Mayor) Frank L. Rizzo, a fiamboyant figure who "liked to call himself the toughest cop in America." Berson, "The Toughest Cop in America" Campaigns for Mayor of Philadelphia, N.Y. Times, May 16, 1971, $\$ 6$ (Magazine), at 30 (hereinafter cited as The Toughest Cop). Rizzo was repeatedly charged with brutality during his rise through the ranks of the police department, N.Y. Times, Nov. 7, 1982, at 30, col. 1, and even during his tenure as Commissioner. The Toughest Cop, supra, at 56-57.

280. The first action, Goode v. Tate, was brought by Goode and two other individuals; the second, Council of Orgs. on Philadelphia Police Accountability \& Responsibility (COPPAR) v. Rizzo, was brought by 21 persons and four organizations. 357 F. Supp. 1289 (E.D. Pa. 1973), aff $d$ sub nom. Goode v. Rizzo, 506 F.2d 542 (3d Cir. 1974), rev'd, 423 U.S. 362 (1976). COPPAR was an unincorporated association of 32 comınunity groups. Rizzo v. Goode, 423 U.S. at 364 n.l.

281. COPPAR v. Rizzo, 357 F. Supp. 1289, 1291 (E.D. Pa. 1973), affd sub nom. Goode v. Rizzo, 506 F.2d 542 (3d Cir. 1974), rev'd, 423 U.S. 362 (1976).

282. COPPAR v. Rizzo, 357 F. Supp. 1289, 1291 (E.D. Pa. 1973), affd sub nom. Goode v. Rizzo, 506 F.2d 542 (3d Cir. 1974), rev'd, 423 U.S. 362 (1976). 
held over twenty-one days, ${ }^{283}$ and inade detailed findings of fact. ${ }^{284}$ The court found that there was no "overall Police Department policy to violate the legal and constitutional rights of citizens, nor to discriminate on the basis of race."28s The record did show, however, "that such violations do occur, with such frequency that they cannot be dismissed as rare, isolated instances; and that little or nothing is done by city authorities to pumish such infractions, or to prevent their recurrence."286 The court declined to order appointment of a receiver or even civilian review of police activities. Instead, the judge ordered the defendants to submit a plan to establish new police department procedures for receiving, investigating, and adjudicating civilian complaints against the police. ${ }^{287}$ The court of appeals affirmed, finding the rehef ordered "limited and inoderate in tone." 288

The Supreme Court reversed.289 First, the Court questioned whether the named plaintiffs presented an actual case or controversy. Plaintiffs' "claim to 'real and immediate' injury," said the Court, "rests not upon what the nained [defendants] inight do to them in the future . . . but upon what one of a sinall, unnained minority of pohicemen might do to thein in the future." 290 Thus, the Court concluded that the named plaintiffs lacked a concrete personal stake in the reform of police disciplinary procedures. ${ }^{291}$

Second, the Rizzo Court accused the district court of adopting "an unprecedented theory of $\S 1983$ liability"292 by holding defendants accountable for failing to supervise adequately their subordinates. The

283. Rizzo v. Goode, 423 U.S. 362, 367 (1976).

284. See COPPAR v. Rizzo, 357 F. Supp. 1289, 1294-1316 (E.D. Pa. 1973), affd sub nom. Goode v. Rizzo, 506 F.2d 542 (3d Cir. 1974), rev'd, 423 U.S. 362 (1976). The district court consolidated the cases for final judgment. COPPAR, $357 \mathrm{~F}$. Supp. at 1290.

285. COPPAR v. Rizzo, 357 F. Supp. 1289, 1319 (E.D. Pa. 1973), aff'd sub nom. Goode v. Rizzo, 506 F.2d 542 (3d Cir. 1974), rev'd, 423 U.S. 362 (1976).

286. COPPAR v. Rizzo, 357 F. Supp. 1289, 1319 (E.D. Pa. 1973), affd sub nom. Goode v. Rizzo, 506 F.2d 542 (3d Cir. 1974), rev'd, 423 U.S. 362 (1976).

287. COPPAR v. Rizzo, 357 F. Supp. 1289, 1320-21 (E.D. Pa. 1973), affd sub nom. Goode v. Rizzo, 506 F.2d 542 (3d Cir. 1974), rev'd, 423 U.S. 362 (1976). The Supreme Court described the relief that the district court ordered. The Police Commissioner promulgated a 14-page set of guidelines and posted it in various public areas. The police department prepared a court-approved citizens complaimt form and inade it available to the public. The police department was ordered to amend the police traming manual to reflect the guidelines, and the department was ordered to maintain adequate statistical records to allow court evaluations of the new procedures. Rizzo v. Goode, 423 U.S. 362, 365 n.2 (1976).

288. Goode v. Rizzo, 506 F.2d 542, 547 (3d Cir. 1974), rev'd, 423 U.S. 362 (1976).

289. Rizzo v. Goode, 423 U.S. 362 (1976).

290. Id. at 372 .

291. Id. at 372-73. For a penetrating analysis of this portion of the Court's opinion, see Fiss, supra note 226 , at $1156-58$.

292. 423 U.S. at 373. 
Supreme Court appeared to disagree with the district court's conclusion that the proof showed a pattern of misconduct. ${ }^{293}$ The Court also asserted that there was "no affirmative link between the occurrence of the various incidents" of misconduct by "individual pohice officers not named as parties" and the "adoption of any plan or policy by petitioners--express or otherwise-showing their authorization or approval of such misconduct."294 The Court brushed aside the contentions that the plaintiffs had a " 'right' to be protected from unconstitutional exercises of police power," 295 and that in light of demonstrated patterns of police misconduct, the defendants had a corresponding constitutional duty to take steps to control their charges. "Such reasoning," the Court indicated, "blurs accepted usages and meanings in the English language in a way which would be quite inconsistent with the words Congress chose in $\S 1983$. We have never subscribed to these amorphous propositions, and we decline to do so now."296 The Court concluded that the considerations of federalisin developed in Younger and O'Shea militated against intervention:

Thus the principles of federalism which play such an important part in governing the relationship between federal courts and state governments ... likewise have applicability where injunctive relief is sought, not against the judicial branch of the state government, but agamst those in charge of an executive branch of an agency of state or local governunent. 297

The Rizzo inajority opmion did not mention the legislative history of Reconstruction, perhaps because the Court's conclusions find virtually no support in the legislative debates. The abuses by law enforcement officials in Philadelphia were quite similar to, although less extreme than, the abuses of their counterparts in the post-Civil War South. Racially-motivated brutahty directed at blacks by law enforceinent officials ${ }^{298}$ and private individuals, ${ }^{299}$ and state and local officials' failure to provide protection were predominant congressional concerns during the debates on the fourteenth amendment and its enforcement legislation. ${ }^{300}$ These measures were enacted to enable the federal

293. Id. at 367-68, 373.

294. Id. at 371 (emphasis in original).

295. Id. at 377.

296. Id. at 376.

297. Id. at 380.

298. See supra note 141 and accompanying text.

299. See supra notes 141-42, 161-62 and accompanying text.

300. See supra note 170 for expressions of concern over violence. See supra notes $62,68,91$, $151,163,171-72$ and accompanying text for complaints that local criminal justice officials were failing to protect the freedmen. 
courts to remedy officials' failure to provide for basic physical security. ${ }^{301}$

Congress's purposes emerged with particular clarity during the debates on the Civil Rights Act of 1871, which contained the provision now codified as 42 U.S.C. $\S 1983$. The debates reveal that the district judge in Rizzo correctly construed the reach of that statute and of the fourteenth amendment when he held Philadelphia's police leadership accountable for individual officers' violations. It was the Supreme Court that offered a novel and unsupportably narrow theory of section 1983 liability. In the spring of 1871 , many legislators argued that the highest duty of government was the protection of the citizenry from violence and injustice. ${ }^{302}$ These legislators believed that state officials violated the fourteenth amendment when they failed or refused to provide equal protection, ${ }^{303}$ and that the federal courts could require state officials to discharge their duties in an even-lianded manner. ${ }^{304}$ Congress passed section 1983 specifically to create a private right of action in federal court for injunctive and other relief against state officials who failed in their duty to protect persons against racially-motivated violence and discrimination. ${ }^{305}$ Congress wanted section 1983 to be "liberally and beneficially construed."306 Thus, the Supreme Court in

301. The Freedmen's Bureau bill would have allowed the President to send in military forces when by reason of "any State or local law, ordimance, police or other regulation, custom, or prejudice" blacks did not "have full and equal benefit of all laws and proceedings for the security of person." (emphasis added). See E. MCPherson, supra note 27, at 73-74; supra note 64 and accompanying text. The Civil Rights Act of 1866 was euacted to secure to freedmen the rights of hife, hberty, and property in face of the failure or refusal of state officials to enforce these rights. See supra notes 85-86, 88-89, 91 and accompanying text. The debates on section 1 of the fourtecnth amendinent make clear that its primary purpose was to enable Congress to pass legislation requiring states to administer justice fairly and to "constitutionalize" the basic guaranties of the 1866 Civil Rights Act. See supra notes 130-31 and accompanying text.

302. See supra note 178 and accompanying text.

303. See CONG. GloBE, 42nd Cong., 1st Sess. 482 (1871). Other legislators agreed with this interpretation of the fourteenth amendment. See, e.g., id. at 501 (remarks of Sen. Frelinghuysen) ("A State denies equal protection whenever it fails to give it."); see also id. at 334 (Rep. Hoar), app. 80 (Rep. Perry), 251 (Seu. Morton), app. 300 (Sen. Stevenson), app. 35 (Rep. Burchard), 459 (Rep. Coburn), 697 (Seu. Edmunds).

304. See supra note 303 and accompanying text; see also Monell v. New York City Dep't of Social Servs., 436 U.S. 658, 670-72 (1978).

305. See supra notes $185-86$ and accompanying text.

306. See supra notes $183-84$ and accompanying text. The dissenting judges vigorously attacked the majority's restriction of the scope of section 1983 on the ground that it was inconsistent with the language of section 1983 and with prior Supreme Court and court of appeals cases. Because section 1983 makes a state official responsible if he "subjects, or causes to be subjected" any other person to deprivation of federally secured rights, the dissenters argued that "an official may be enjoined from consciously permitting his subordinates, in the course of their dutics, to violate the constitutional rights of persons with whom they deal." 423 U.S. 362, 385 (Blackmun, Brennan, and Marshall, JJ., dissenting). The dissent also asserted that the majority's narrow interpretation of section 1983 "casts aside reasoued conclusions to the contrary reached by the Courts of Appeals of 10 Circuits." 423 U.S. at 385 \& n.2. 
Rizzo misconstrued Congress's intent when it rejected plaintiffs' assertion that they had a right to be protected from pohce misconduct and that pohice department commanders had a corresponding constitutional duty to see that plaimtiffs were protected.

Defenders of the Court's position might argue that the abuses which caused Congress to pass section 1983 are distinguishable from the abuses in Philadelphia. During Reconstruction, Congress was concerned with state officials' failure to restram private violence by the $\mathrm{Ku}$ Klux Klan, ${ }^{307}$ not with State officials' failure to restrain their own subordinates. Nevertheless, this difference does not justify protecting Philadelphia police supervisors from section 1983 hability for their subordmates' actions. If state officials can be subjected to section 1983 liability for failing to protect the citizenry from vigilantes, they likewise can be held accountable for failing to protect the citizenry from state and muncipal employees, who are directly under the officials' control according to state law. ${ }^{308}$ Officials' failure to control subordinates thus fits within Congress's general purposes in enacting section 1983 and the fourteenth amendment. Moreover, such failure is action "under color of" state law even more clearly than failure to protect against private lawlessness.

The Rizzo Court should not have relied on amorphous notions of federalism to support its decision to decline to exercise federal jurisdiction. ${ }^{309}$ The constitutional and statutory enactments of the Reconstruction era wrought permanent changes in the pre-Civil War relationship between the state and federal governments. To the extent the Younger doctrine is founded on a conception of federahsm that is inconsistent

307. See supra notes 171-72 and accompanying text.

308. Under Pennsylvania law, the Managing Director of Philadelphia is responsible for supervising the activities of the City's Police Commissioner. The Police Commissioner in turn has responsibility for supervision and control of the police department. COPPAR v. Rizzo, $357 \mathrm{~F}$. Supp. 1289, 1292 (E.D. Pa. 1973), aff'd sub nom. Goode v. Rizzo 506 F.2d (3d Cir. 1974), rev'd, 423 U.S. 362 (1976); $c$. Monell v. New York City Dep't of Social Servs., 436 U.S. 658, 673-80 (1978) (Both opponents and supporters of the Civil Rights Act of 1871 agreed that Congress could impose civil damage liability on a municipality that was obligated to keep the peace under state law but failed to do so in violation of the fourteenth amendment.).

309. Moreover, it is not even clear in Rizzo that theoretically available state remedies existed. The district court reviewed both judicial and nonjudicial remedies and found them to be untenable. COPPAR v. Rizzo, 357 F. Supp. 1289, 1292-94, 1319-20 (E.D. Pa. 1973), aff'd sub nom. Goode v. Rizzo, 506 F.2d 542 (3d Cir. 1974), rev'd, 423 U.S. 362 (1976). The Supreme Court never considered whether alternative state remedies existed. This omission prompted Owen Fiss to remark:

In strikmg contrast to [O'Shea $v$. Littleton], there is no pretense that the federal injunctive remedy is being denied because there is an alternative adequate remedy. The value preference is more starkly embraced: even if no other renedy is available, the doors of the federal equity court will be closed.

Fiss, supra note 226, at 1159 (emphasis in origmal); see also Weinberg, supra note 278, at 1224-25. 
with the fourteenth amendment and concomitant congressional action, it should be abandoned. ${ }^{310}$

\section{The Cases Extending Younger to State Civil Proceedings.}

Younger, O'Shea, and Rizzo all concerned federal court intervention in state criminal justice systems. During the 1970's, the Supreme Court extended the Younger doctrine to selected civil cases. ${ }^{311}$ In Huffman v. Pursue, Ltd. , ${ }^{312}$ Ohio brought civil actions under its obscenity laws to stop the showing of allegedly obscene movies in a local theater. After a state court granted an order of abateinent, the theater owner instituted a federal action challenging the obscenity statute. The Supreme Court ordered abstention, holding that the Younger principles apphed to state civil proceedings when "the State is a party . . . and the proceeding is both in aid of and closely related to criminal statutes." 313 In Juidice v. Vail, ${ }^{314}$ Vail was imprisoned briefly for civil contempt after ignoring the orders of a state court in a proceeding brought to enforce a previous civil judgment. He brought a federal class action seeking to enjom operation of the statutory contempt procedures on the ground that they violated due process. The Supreme Court ordered abstention, stressing the importance of a "State's imterest in the contempt process, through which it vindicates the regular operation of its

310. Instead of abandoning the Younger doctrine, however, the Supreme Court continues to reinforce it. The Court relied upon O'Shea and Rizzo in ordering dismissal of a section 1983 action that sought to enjoin the use of a dangerous choke hold by members of the Los Angeles Pohce Department in situations where the officers were not threatened with inmediate physical harm. See Los Angeles v. Lyons, 457 U.S. 1115 (1983). As in O'Shea and Rizzo, the Lyons Court concluded that the abstention doctrime precludes relief and made no mention of the legislative history of the Reconstruction enactinents. Lyons draws no more support from that history than do $O$ 'Shea and Rizzo.

Much of the Supreine Court inajority opinion is devoted to Lyons's supposed lack of slanding to seek injunctive relief. Id. at 4426-28. The Court also relied, however, on the Younger doctrine. Invocation of abstention principles in Lyons is wholly at odds with the intent of Reconstruction legislators. Lyons alleged that Los Angeles police were brutalizing and in some instances killing blacks without justification. Racially-inotivated beatings and the slaughter of blacks by southern law enforcement officials and private individuals, and the persistent failure of southern justice systems to protect against these and other forns of discrimmation, were the chief complaints of the Reconstruction Congresses. See supra notes 85-86, 91, 120, 141-42, 149-51, 170-71 and accompanying text. Because the fourteenth amendinent and enforcement legislation were passed specifically to enable the federal courts to reach the sort of official lawlessness alleged in Lyons, Younger abstention was inappropriate.

311. For commentary on the extension of Younger to civil cases, see generally Aldisert, On Being Civil to Younger, 11 CoNN. L. Rev. 181 (1979); Bartels, Avoiding a Comity of Errors: $A$ Model for Adjudicating Federal Civil Rights Suits That "Interfere" with State Civil Proceedings, 29 STAN. L. REV. 27 (1976).

312. 420 U.S. 592 (1975).

313. Id. at 604 .

314. 430 U.S. 327 (1977). 
judicial system."315 Federal court interference with this process, said the Court, would be " an offense to the State's interest . . . every bit as great as it would be were this a criminal proceeding." "316

Trainor v. Hernandez ${ }^{317}$ involved state-initiated civil actions to recover welfare payments that the State of Illinois claimed had been obtamed through fraud. The defendants in those proceedings brought a federal action challenging attachment of their assets by the state without notice or other procedural safeguards. The Supreme Court held that Younger applied because Illinois was a party to the state court actions, and "[b]oth the suit[s] and the accompanying writ[s] of attachment were brought to vindicate important state policies such as safeguarding the fiscal integrity of those programs." 318 Finally, in Moore v. Sims ${ }^{319}$ the Supreme Court ordered the federal district court not to interfere with pending state court proceedings in which the State of Texas had taken custody of the federal plaintiffs' children to protect them from alleged child abuse. The Court noted that Texas was a party to the state proceedings, which were instituted to further a vital state interest. ${ }^{320}$

Although these four cases were brought pursuant to the fourteenth amendment and sections 1343 and 1983, the majority opinions never inention the legislative history of the enactments. ${ }^{321}$ Reexamination of

315. Id. at 335 .

316. Id. at 336 (quoting Huffman, 420 U.S. at 604).

317. 431 U.S. 434 (1977).

318. Id. at 444 . The Court remanded for inquiry into whether the plaintiffs could have presented their due process challenge in the peuding state proceedings. Id. at $447-48$.

319. 442 U.S. 415 (1979).

320. $I d$. at 423,435 . For a thoughtful analysis of this decision, see Note, Moore v. Sims: $A$ Further Expansion of the Younger Abstention Doctrine, 1 PACE L. REv. 149 (1980).

321. The dissenting justices, and Justice Brennan in particular, argued that abstention in these cases was inconsistent with congressional intent. See Moore v. Sims, 442 U.S. 415, 437 (1979) (Stevens, J., dissenting); Trainor v. Hernandez, 431 U.S. 434, 450, 456 (1977) (Brennan, J., dissenting); Huffman v. Pursue, Ltd., 420 U.S. 592, 616-17 (1975) (Brennan, J., dissenting). Justice Brennan's dissent in Juidice was vehement:

[T] he Court effectively cripples the congressional scheme enacted in $\S 1983$. The crystal clarity of the congressional decision and purpose in adopting $\S 1983$, and the unbroken hine of this Court's cases enforcing that decision, expose Huffman and today's decision as deliberate and conscious floutings of a decision Congress was constitutionally einpowered to make. lt stands the $\S 1983$ remedy on its head to deny the $\S 1983$ plaintiff access to the federal forum because of the pendency of the state civil proceedings where Congress intended that the district court should entertain his suit without regard to the pendency of the state suit.

Juidice v. Vail, 430 U.S. at 343 (Brennan, J., dissenting) (emphasis in original). Although eloquently stated, Justice Brennan's dissents speak only in general terms about Congress's purposes and rely primarily on other recent Supreme Court cases. His arguments are strengthened considerably by examining the legislative record in greater detail. $C$ f. Patsy v. Board of Regents, 457 U.S. 496, 502-07 (1982) (detailed exanination of legislative history shows Congress did not mean to require exhaustion of the state adinmistrative remedies in section 1983 actions); Monell v. New 
these decisions in light of the legislative history suggests that application of the Younger doctrine was improper. First, if the legislative history cuts the Younger doctrine off at its roots in the criminal area, spread of the doctrine to civil cases is unwarranted. In addition, the debates show that throughout Reconstruction, Congress was deeply disturbed by the systemic maladininistration of civil justice in the South. ${ }^{322}$ The Black Codes were enforced by civil as well as crininal processes. ${ }^{323}$ In 1865-1866, numerous southern whites instituted civil suits under the Codes agamst Arny and Freedmen's Bureau personnel. ${ }^{324}$ Section 1 of the fourteenth ainendinent was enacted priniarily to give Congress the power to reforin errant state justice systems, both civil and criminal; 325 most of the numerous enforcement statutes that Congress passed under this authority sought to ensure equal treatment in civil inatters. ${ }^{326}$

A strict interpretivist inight argue that the Court was nonetheless correct to decline federal jurisdiction in Huffman, Juidice, Trainor, and Moore because the specific claims in those cases were not contemplated by Reconstruction legislators. ${ }^{327}$ It is, of course, true that from 1865 to 1871 , Congress was not thinking of the unfair deprivation of property

York City Dep't of Social Servs., 436 U.S. 658, 665-89 (1978) (detailed examination of legislative history shows Congress imtended municipalities to be persons within meaning of section 1983).

322. See supra notes 151, 171-72, 177 and accompanying text.

323. In South Carolina, for exainple, no black could be anything other than a farm laborer or servant without paying a fee and obtaiming a license from a judge, and new courts were established with exclusive jurisdiction of all civil causes where one or both parties were black. See supra notes 39,44 and accompauying text.

324. State and local lawyers, judges, and juries apphed the civil sanctions of the Codes against Army and Bureau personnel for interference with blacks' labor contracts and for other alleged wrongs.

325. See supra notes $\mathbf{1 2 5 - 3 0}$ and accompanying text.

326. The Freedmen's Bureau bill would have extended to blacks "the right to make and enforce contracts, to sue, be parties and give evidence . . . and to have full and equal benefit of all laws and proceedings for the security of person and estate." See supra text accoinpanying note 64. The 1866 Civil Rights Act stated that blacks were to have the same right as whites "to make and enforce contracts, to sue, be parties and give evidence, to inherit, purchase, lcase, sell, hold and convey real and personal property." See supra text accompanying note 80.

The May 11, 1866 ainendinents to the 1863 Habeas Corpus and Removal Act made removal of civil cases from state to federal court easier. See supra note 137 and accompanying text. The Separable Controversies Act was passed to counter plaintiffs' practice in southern courts of joining a local defendant in suits against northerners to destroy complete diversity and thus prohibit reinoval to federal court. $I d$.

The debates on the 1871 Civil Rights Act focused on criminal justice reform. Nonethelcss, in discussing section 1983 legislators spoke in terms that encompassed the administration of justice generally, see supra notes $171-72,177$ and accompanying text, and made no attempt to limit section 1983 remedies to reform of state criminal justice systems. See, e.g., CoNG. GlobE, 42d Cong., 1st Sess. app. 185 (1871) (remarks of Rep. Platt).

327. See supra note 13 . 
of theater owners, imprisonment under unconstitutional civil contempt procedures, attachment of funds without notice or an opportunity to be heard in welfare recoupment proceedings, or removal of children from their parents without a prior hearing. ${ }^{328}$ Instead, Congress was concerned with anny and Freedmen's Bureau officials unfairly being held civilly liable in state courts for aiding freedmen, and with general discrimination and procedural unfairness in state civil suits because of race, employinent status, or political opinion.

Despite the dissimilarities, the nature of the potential state court problem that the Reconstruction Congresses souglit to remedy has not changed in the intervening century. That state justice systems have not in the last decade manifested the level of racism, hatred, and bigotry that marked the post-Civil War era is no guarantee that state systems will not again becone the bastions of sucl ill will. Indeed, the civil rights reforns of the 1960's demonstrated how enduring soine of these problems are. The Constitution, and particularly the fourteentl amendment, is the only safeguard against such abuse. After the Civil War persons were being deprived of liberty and property without due process of law, and the deprivations occurred because judges im civil state court proceedings failed to accord the procedural fairness required by the Constitution. Viewed in this manner, the exercise of jurisdiction in Huffiman, Juidice, Trainor, and Moore would have been at least consistent with legislative intent. Moreover, even an interpretivist may properly "seek to determine whetlıer a given issue falls within the scope of evils the framers addressed." 329

\section{E. Lower Federal Court Decisions.}

O'Shea v. Littleton, Rizzo v. Goode, and the civil Younger cases sent the lower federal courts a clear niessage: in the future, be extremely reluctant to order declaratory or injunctive relief that might interfere with the administration of justice in the states. The lower courts heard the message, and generally have declined to use their equitable powers to reform state criminal and civil justice systems. A sampling of the case law reveals the magnitude of the lower courts' abdication of their responsibilities under tlie fourteentl ainendment and sections 1343 and 1983.

328. Congress did consider an analogous child custody problem. The Mississippi Black Code required local officials to report to probate courts all black children whose parents could not support them so that they could be apprenticed to a suitable person. See supra note 38 and accompanying text. The Civil Rights Act of $1866, \mathrm{ch} .31,14$ Stat. 27, presumably overturned this provision.

329. See Grano, supra note 233 , at 18 . 
In the criminal justice area, the lower federal courts have dismissed section 1983 cases alleging improper police conduct, ${ }^{330}$ delays in arraignment, ${ }^{331}$ unconstitutional bail practices, ${ }^{332}$ coercion of guilty pleas, ${ }^{333}$ denial of the right to counsel, ${ }^{334}$ inadequate representation by counsel, ${ }^{335}$ denial of speedy trial, ${ }^{336}$ unconstitutional procedures for selecting petit and grand jurors, ${ }^{337}$ failure to provide transcripts to indigent defendants, ${ }^{338}$ unconstitutional practices in the conduct of trials, ${ }^{339}$

330. See, e.g., Robinson v. Stovall, 473 F. Supp. 135, $143-47$ (N.D. Miss. 1979) (Younger bars suit against city officials to enjoin brutal treatment and intinidation pursuant to unconstitutional ordinance banning demonstrations), aff $d$ in part and rev'd in part, $646 \mathrm{F.2d} 1087$ (5th Cir. 1981).

331. See, e.g., Dommer v. Crawford, 638 F.2d 1031, 1036 (7th Cir. 1980) (Younger bars class action seeking injunction ordering state officials to comply with state law requiring arraignment before inagistrate within tweuty-four hours of arrest), withdrawn and amended opinion issued, 653 F.2d 289, 291 (7th Cir. 1981). But see Conover v. Montemuro, 477 F.2d 1073, 1081 (3d Cir. 1972) (Younger no bar to suit challenging intake procedures and lack of preliminary hearings in Philadelphia Family Court).

332. See, e.g., Tarter v. Hury, 646 F.2d 1010, 1013 (5th Cir. 1981) (Younger doctrine bars suit by defendants in state criminal proceedings claiming imposition of excessive bail); Rivera v. FreeInan, 469 F.2d 1159, 1164 (9th Cir. 1972) (Younger bars challenge to Califoruia statutes governing detention of juveniles). But see Hunt v. Roth, 648 F.2d 1148, 1154 (8th Cir. 1981) (Younger does not bar challenge to section of Nebraska constitution denying bail to persons charged witl certain sex offenses), vacated as moot sub nom. Murphy v. Hunt, 455 U.S. 478 (1982) (per curiam).

333. See, e.g., Bonner v. Circuit Court, 526 F.2d 1331, 1335-38 (8th Cir. 1975) (en banc) (federal court should abstain in suit by black state criminal defendants alleging that judges, prosecutors, and defense lawyers had joined in a systematic, racially-motivated conspiracy to coerce guilty pleas), cert. denied, 424 U.S. 946 (1976).

334. See, e.g., Williams v. Rubiera, 539 F.2d 470, $473-75$ (5th Cir. 1976) (Younger bars challenge by defendant in pending state prosecution for welfare fraud who wants counsel assigned, even though fine is only possible sentence), cert. denied, 431 U.S. 931 (1977); Bedrosian v. Mintz, 518 F.2d 396, 399-400 (2d Cir. 1975) (federal court should not direct state judge to appoint out-ofstate counsel requested by defendant in criminal prosecution). But see Flynt v. Leis, 574 F.2d 874, 879-82 (6th Cir. 1978) (federal district court could enjoin state judge from barring out-of-state counsel in criminal case because counsel had no adequate alternative means to clallenge the state court order), rev'd on other grounds, 439 U.S. 438 (1979).

335. See, e.g., Gardner v. Luckey, 500 F.2d 712, 715 (5th Cir. 1974) (Younger barred class suit by convicted state prisoners challenging representation of Florida Public Defender), cert. denied, 423 U.S. 841 (1975); Wallace v. Kern (I), 481 F.2d 621, 622 (2d Cir. 1973) (federal court refused on comity grounds to limit caseloads of Legal Aid attorneys), cert. denied, 414 U.S. 1135 (1974).

336. See, e.g., Wallace v. Keru (II), 499 F.2d 1345, 1351 (2d Cir. 1974) (Younger barred imjunction setting tine limits for commencement of state trials and requiring release of defendants on recognizance for noncompliance), cert. denied, 420 U.S. 947 (1975).

337. See, e.g., Diaz v. Stathis, 576 F.2d 9, 11 (1st Cir. 1978) (Younger doctrine precludes suit by defendants and a plaintiff in pending state criminal and civil proceedings seeking injunctive relief reforming discriminatory state procedures for picking petit and grand jurors); Bryant v. Morgan, 451 F.2d 354, 355 (5th Cir. 1971) (Younger bars constitutional attack on trial jury selection procedures by persons under indictnent in state court). But see Ciudadanos Unidos de San Juan v. Hidalgo County Grand Jury Comm'rs, 622 F.2d 807, 830 n.49 (5th Cir. 1980) (Younger no bar to class action by community residents seeking prospective injunctive relief agaimst discriminatory grand jury selection procedures), cert. denicd, 450 U.S. 964 (1981); Penn v. Eubanks, 360 F. Supp. 699, 702 (M.D. Ala. 1973) (same).

338. See, e.g., Leslie v. Matzkin, 450 F.2d 310, 312 (2d Cir. 1971) (Younger doctrine precludes suit seeking to compel Connecticut officials to provide indigent defendants with copies of prehiminary learing transcripts in advance of trial), cert. denied, 406 U.S. 932 (1972). 
and improper mental hospital assignment policies. ${ }^{340}$ In the civil justice area, the lower federal courts have declined to exercise their jurisdiction in section 1983 cases seeking to overturn a state court injunction prohibiting demonstrations protestimg racial discrimination, ${ }^{341}$ to ensure procedural fairness in state proceedings to revoke a driver's license, ${ }^{342}$ and to enjoin professional disciplinary procedures on due process grounds. ${ }^{343}$ Courts have also declined to hear section 1983 cases brought by plaintiffs challenging a state rule of civil procedure adding damages agaimst defendants for delay in civil cases, ${ }^{344}$ attacking municipal ordmances governing eminent domain procedures, ${ }^{345}$ and seeking to require a state to provide adequate facihties for the proper functioning of the civil and criminal justice systems. ${ }^{346}$

As with the Supreme Court cases that they mimic, these lower court decisions find little support in the legislative history of Reconstruction. The practices complamed about in at least some of the cases cited above are virtually identical to the evils that prompted the Reconstruction enactments. For example, police brutality and failure to provide protection, discriminatory bail practices, and failure of judges to accord procedural fairness in the conduct of trials were all specifically objected to by Reconstruction legislators. ${ }^{347}$ The challenged proce-

339. See, e.g., Parker v. Turner, 626 F.2d 1, 2 (6th Cir. 1980) (Younger bars class action charging state juvenile court judges with denying basic due process in civil contempt proceedings against indigent fathers behind in support paynents); New Jersey v. Chesimard, 555 F.2d 63, 68 (3d Cir. 1977) (en banc) (Younger precludes suit by defendant in pending state criminal proceeding seeking to enjoin state court from holding trial on Friday, Mushin holy day); Manns v. Koontz, 451 F.2d 1344, 1345 (4th Cir. 1971) (Younger bars challenge to state law placing exclusive jurisdiction of criminal case im domestic relations court that does not afford jury trial).

340. See, e.g., Coley v. Clinton, 635 F.2d 1364, 1371-72 (8th Cir. 1980) (Younger doctrine bars class suit challenging Arkansas mental hospital pohicy of assigning criminal defendants to maximun security wards while assigning other involuntarily comunitted persons to open wards, and challenging commitunent and release procedures).

341. See, e.g., Blue v. Revels, 441 F. Supp. 308, 311-12 (M.D. Fla. 1977).

342. See, e.g., Sartin v. Comunissioner of Pub. Safety, 535 F.2d 430, 433-34 (8th Cir. 1976) (Younger bars suit challenging racial discrimimation by pohice and revocation of hicense without due process); United States ex rel. Hudsou v. Wollenzien, 345 F. Supp. 436, 438 (E.D. Wis. 1972) (court cited Younger in disumssing suit seeking declaratory judgunent that plaintiff is entitled to a jury trial on the issue of the reasonableness of his refusal to submit to blood alcohol test in proceedings brought to suspend his driving privileges).

343. See, e.g., Anonymous v. Association of the Bar, 515 F.2d 427, $432-34$ (2d Cir.), cert. denied, 423 U.S. 863 (1975); Erdinann v. Stevens, 458 F.2d 1205, 1210 (2d Cir.), cert. denied, 409 U.S. 889 (1972); Del Rio v. Kavanagh, 441 F. Supp. 220, 224 (E.D. Mich. 1977).

344. See Insurance Fed'n v. Supreme Court, 489 F. Supp. 89, 93 (E.D. Pa. 1980), affd, 669 F.2d 112 (3d Cir. 1982).

345. See Ahrensfeld v. Stephens, 528 F.2d 193, 198 (7th Cir. 1975).

346. Ad Hoc Comm. on Judicial Admin. v. Massachusetts, 488 F.2d 1241, 1246 (1st Cir. 1973), cert. denied, 416 U.S. 986 (1974).

347. See supra notes $85-86,91,93-94,106-09,149-51,161-63,170-77$ and accompanying text. 
dures in many of the other cases in which the lower federal courts have declined to intervene are very similar to the unfair practices Congress addressed. Denial of counsel, denial of speedy trial, failure to provide transcripts, and failure to provide procedural fairness im civil cases involving property or liberty interests all involve systemic deprivations of due process or equal protection of the same quality and kind that motivated the Reconstruction Congresses to act. It is, of course, possible, and perhaps even likely, that if the federal courts had heard these eases, they would have found for the defendants or granted only limited relief. But to assume the truth of the plaintiff' claims, as the federal courts must on a inotion to dismiss under Rule 12(b)(6) of the Federal Rules of Civil Procedure, ${ }^{348}$ and then to refuse to hear them, is wholly unwarranted given the legislative history. ${ }^{349}$

It can be argued that because the fourteenth amendment and the enforcement acts were aimed at problems in the South immediately following the Civil War, it is inappropriate to use them as the basis of a

348. Cooper v. Pate, 378 U.S. 546 (1964).

349. The Supreme Court cases refusing to require exhaustion of state judicial or administrative remedies in section 1983 actions lend support to the thesis that federal courts should intervene in circumstances that have recently been held to fall within Younger's purview. See Patsy v. Board of Regents, 457 U.S. 496 (1982); Barry v. Barchi, 443 U.S. 55, 63 n.10 (1979); Gibson v. Berryhill, 411 U.S. 564, 574 (1973); Carter v. Stanton, 405 U.S. 669, 671 (1972); Wilwording v. Swenson, 404 U.S. 249, 251 (1971); Houghton v. Shafer, 392 U.S. 639, 640 (1968); Damico v. California, 389 U.S. 416 (1967); Monroe v. Pape, 365 U.S. 167, 171-83 (1961). In Patsy, 457 U.S. at 502-07, the Court carefully reviewed the debates of the 1871 Civil Rights Act, and cited many of the legislative remarks discussed in part I of this Article in support of its holding that exhaustion of administrative remedies should not be required in section 1983 cases. Georgia Patsy alleged that her employer, Florida International University, discriminated on grounds of race and sex in denying her employment opportunities. The Fifth Circuit required her to exhaust available administrative remedies, Patsy v. Florida Int'l Univ., 634 F.2d 900, 913-14 (5th Cir. 1981) (en banc), rev'd, 457 U.S. 496 (1982). The Supreme Court disagreed. The Court pointed to three themes in the legislative debates to support its refusal to impose an exhaustion requirement. First, "Congress assigned to the federal courts a paramount role in protecting constitutional rights" when it passed section 1 of the Civil Rights Act. 457 U.S. at 503. Second, a major motivating factor in enacting section 1 was distrust of the state courts. Id. at 505. Third, legislators explicitly interpreted section 1 as providing concurrent federal and state court forums, "enabling the plaintiff to choose the forum in which to seek relief." Id. at 506 .

The same legislative history that compels the conclusion that Congress did not mean to require exhaustion of state remedies in section 1983 cases demonstrates even inore clearly that Congress did not mean to require federal courts to abstain in Younger-type cases. Indeed, if Congress rejected exhaustion, which contemplates a possible return to federal court if state remedies are unavailing, it also must have rejected abstention, which bars the doors to the lower federal courts completely. Justice Powell recognized the inconsistency of Younger and the exhaustion cases in his dissenting opinion: "[A] categorical no-exhaustion rule would seem inconsistent witl the decision in Younger v. Harris . . . prescribing abstention when state criminal proceedings are pending. At least where administrative proceedings are pending, Younger would seem to suggest the appropriateness of exhaustion." Id. at 533-34 (citation omitted). Equally, of course, non-exhaustion cases such as Patsy suggest the inappropriateness of Younger abstention. 
nationwide litigation campaign to work systemic reform in state justice systems in the 1970's and 1980's. It is difficult, however, to argue credibly that the fourteenth amendment and section 1983 apply only to the South or that their provisions have somehow expired or lost force with the passage of time. Nor can it seriously be contended that constitutional provisions or broad remedial statutes are limited in scope to the precise events that caused their enactment. 350

In addition, it seems particularly appropriate to apply the Reconstruction measures to remedy modern deficiencies in the administration of justice because the modern problems can be attributed, in part, to the heritage of slavery. ${ }^{351}$ Racism and poverty contribute to the overwhelming caseloads that are responsible for many of the denials of due process and equal protection in state justice systems. ${ }^{352}$ Therefore, federal courts ought to use the Reconstruction enactments to help solve problems directly descended from the injustices of that Era. ${ }^{353}$

\section{Reed Dickerson has stated:}

Although legislation is usually prompted by specific past situations, legislative draftsmen almost mevitably address their words to classes of events . . . . [T]o deny that the legislator's utterance of general conditions on future behavior is a proper part of the legislative function is to deny that guidance and the establishment of workable frames of reference on which reasonable expectations can be built are among the functions of the legal order.

Dickerson, Statutory Interpretation: A Peek Into the Mind and Will of a Legislature, 50 IND. L.J. 206, 215 (1975).

351. R. Clark, Crime In AMERICA 61-62 (1970).

352. See generally L. Katz, L. Litwin, \& R. BAMgerger, Justice is The Crime: Pre-TRIAL Delay in Felony Cases (1972); President's Commission on Law ENForcement and Administration of Justice, The Challenge of Crime in a Free Society (1967).

353. Federal suits seeking systemic reform of state justice systems typically are brought as class actions under Fed. R. Civ. P. 23(b)(1) and (2). Although courts of equity of the Reconstruction era could entertain class actions, there were many restrictions on their use. See generally $\mathrm{Z}$. Chafee, JR., Some Problems of Equity 199-224 (1950) (origins and development of class suits); Developments in the Law-Class Actions, 89 HARv. L. REv. 1318, 1331-37 (1976) (community of interest as prerequisite for class suit). Chief among these restrictions was the rule that class suits could be brought only on behalf of persons holding "a common interest or a common right" and not on behalf of those holding several and distinct rights. Smith v. Swormstedt, 57 U.S. (16 How.) 288, 302 (1854); see also Ayres v. Carver, 58 U.S. (17 How.) 591, 594 (1855). This requirement presumably precluded most class suits by groups of blacks under Reconstruction legislation. Because Reconstruction legislators could not have foreseen developinent of the modern class action, it might be argued that the legislative history does not support the use of this flexible and powerful device to reform state practices and procedures.

There is no reason, however, to think that Congress would have wanted the federal courts to retaim outmoded procedural rules, or would have denied the courts the opportunity to adopt more moderu procedures as they evolved over time. A contrary intent can be seen in the passage of the Conformity Act in 1872, ch. 255, 17 Stat. 196 (1872). The Conformity Act directed the federal courts, $m$ actions at law, to conform their procedures to those "existing at the time in like causes in the courts of record of the State within which such circuit or district courts are held." Id. at 197. This "dynamic" conformity replaced the earher "static" conformity that had required the federal courts to follow state procedures as of a given date. See P. Bator, P. Mishkin, D. Shapiro \& H.

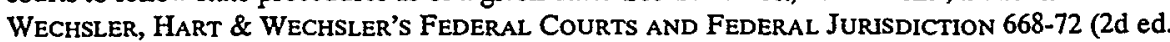




\section{CONCLUSION}

Congress's primary concerns during Reconstruction were the stubborn problems of violence and the maladministration of justice in the South. Congress's primary goals in passing the fourteenth amendment and remedial statutes of that era were to eradicate discriminatory laws and to assure due process and equal protection in state crimmal and civil justice systems. The Congress empowered the federal courts to accomplish these goals, and granted access to a federal forum to the victims of these injustices.

In the 1970's, the federal courts ignored this mandate. The courts' abdication is not without cost. As Harry $\mathrm{H}$. Wellington has noted, a governmental structure that fails to unite a nation's present with its past necessarily fails to preserve values to which its citizens may attach considerable weight. It fails to make a contemporary effort to understand what we have been or have wished as a people to become, and thus it fails to give effect to what might be called the moral ideals of the community. 354

Over 100 years have passed since Reconstruction, but due process and equal protection in state criminal and civil justice systems remain unrealized goals. When state justice systems fail to protect fundamental rights, it is time for the federal courts to exercise their jurisdiction.

1973). Moreover, Congress had given the Supreme Court broad rulemaking authority in equity actions. See Act of Aug. 23, 1842, ch. 188, 5 Stat. 516, 518; see also HART \& WECHSLER, supra, at 664-65 (court rulemaking power reaffirmed by Act of August 23, 1842).

In addition, in seeking systemic reform of southern justice systems, the Reconstruction Congresses authorized the federal courts to use virtually every remedy available at that time. See supra section I. It is thus possible, and perhaps even likely, that the legislators would have heartily approved the current Federal Rule 23, and would have adopted it had they thought of it. For an excellent discussion of the history of the class action, see Yeazell, From Group Litigants to Class Action Part 1: The Industrialization of Group Litigation, 27 U.C.L.A. L. REv. 514 (1980); Yeazell, From Group Litigation to Class Action Part II: Interest, Class, and Representation, 27 U.C.L.A. L. REv. 1067 (1980).

354. Wellington, The Nature of Judicial Review, 91 Yale L.J. 486, 494 (1982). 